\title{
Review \\ Mechanisms of Beta-Cell Apoptosis in Type 2 Diabetes-Prone Situations and Potential Protection by GLP-1-Based Therapies
}

\author{
Safia Costes *, Gyslaine Bertrand and Magalie A. Ravier *(D) \\ IGF, Univ. Montpellier, CNRS, INSERM, 34094 Montpellier, France; gyslaine.bertrand@igf.cnrs.fr \\ * Correspondence: safia.costes@igf.cnrs.fr (S.C.); magalie.ravier@igf.cnrs.fr (M.A.R.); \\ Tel.: +33-4-34-35-92-03 (S.C. \& M.A.R.)
}

\begin{abstract}
Type 2 diabetes (T2D) is characterized by chronic hyperglycemia secondary to the decline of functional beta-cells and is usually accompanied by a reduced sensitivity to insulin. Whereas altered beta-cell function plays a key role in T2D onset, a decreased beta-cell mass was also reported to contribute to the pathophysiology of this metabolic disease. The decreased beta-cell mass in T2D is, at least in part, attributed to beta-cell apoptosis that is triggered by diabetogenic situations such as amyloid deposits, lipotoxicity and glucotoxicity. In this review, we discussed the molecular mechanisms involved in pancreatic beta-cell apoptosis under such diabetes-prone situations. Finally, we considered the molecular signaling pathways recruited by glucagon-like peptide-1-based therapies to potentially protect beta-cells from death under diabetogenic situations.
\end{abstract}

Keywords: pancreatic beta-cells; islets; apoptosis; islet amyloid; lipotoxicity; glucotoxicity; GLP-1

Citation: Costes, S.; Bertrand, G.;

Ravier, M.A. Mechanisms of Beta-Cell Apoptosis in Type 2 Diabetes-Prone Situations and Potential Protection by GLP-1-Based Therapies. Int. J. Mol. Sci. 2021, 22, 5303. https:// doi.org/10.3390/ijms22105303

Academic Editor: Jan Kovár

Received: 7 April 2021

Accepted: 13 May 2021

Published: 18 May 2021

Publisher's Note: MDPI stays neutral with regard to jurisdictional claims in published maps and institutional affiliations.

Copyright: (c) 2021 by the authors. Licensee MDPI, Basel, Switzerland. This article is an open access article distributed under the terms and conditions of the Creative Commons Attribution (CC BY) license (https:// creativecommons.org/licenses/by/ $4.0 /)$.

\section{Introduction}

Type 2 diabetes (T2D) is characterized by chronic hyperglycemia due to an insufficient insulin secretion to effectively lower plasma glucose concentrations in the context of insulin resistance of target tissues. The amount of released insulin depends on the output of each beta-cell from pancreatic islets of Langerhans (beta-cell function) and of the total number of these cells (beta-cell mass). There is evidence that beta-cells have a first compensatory phase to counteract insulin resistance by increasing insulin secretion to maintain euglycemia [1,2]. Indeed, hypersecretion of insulin has been reported in obese patients [3-5], and the beta-cell mass was shown to be increased in obese non-diabetic individuals [6-8] and in insulin resistant patients [9] through neogenesis rather than proliferation $[6,9,10]$, and/or transdifferentiation of both acinar/ductal cells and alpha-cells into beta-cells (see reviews [2,11]). Since insulin secretion measured in vivo [3-5] cannot be correlated to beta-cell mass in the same patient [6-9], it is difficult to investigate their respective contribution in that context, but both seem to contribute to the insulin compensatory increase. Whereas beta-cells seem to compensate for high insulin demand that occurs in obesity, when the compensation mechanisms are lost and beta-cells become exhausted, hyperglycemia appears $[1,2]$.

The alteration in glucose-induced insulin secretion in human T2D was reported to result from beta-cell dysfunction associated or not with a decrease in beta-cell mass. A loss of first- and reduced second-phase insulin responses [12] with alteration of insulin oscillatory release $[13,14]$ are well established beta-cell functional abnormalities in T2D. Beta-cell function in patients with T2D was reported to be reduced by $50 \%$ at diagnosis [15] while the beta-cell mass was only reduced by $24 \%$ [7]. Since patients undergoing hemi pancreatectomy for donation to a relative with type 1 diabetes showed normal 24-h glucose profiles [16], and deterioration of insulin secretion and glucose tolerance one year later [16] with an increased risk of developing T2D only in the presence of obesity and insulin resistance [17], the contribution of the decreased beta-cell mass to the onset of T2D appeared as a subject of debate [6,7]. 
Beta-cell mass cannot yet be accurately measured in living patients; therefore, our knowledge relies on pancreatic tissue sections from autopsies. A significant reduction in beta-cell mass by $40-65 \%$ in subjects with glucose intolerance [6] and in T2D patients $[6,7]$ compared to nondiabetic subjects matched for body mass index (BMI) has been observed, and was also reported by other studies including fewer subjects [18-20]. If the involvement of the decrease in beta-cell mass in T2D onset is still controversial, its gradual decline with duration of the disease undoubtedly contributes to the progressive deterioration of glucose homeostasis [7]. Of note, it was also recently commented that persons with and without T2D can have a similar beta-cell mass, but because of huge variabilities in insulin sensitivity and insulin secretion in the general population, the total mass is inadequate and might be responsible for their diabetes [21].

Several possibilities have been highlighted to explain the default in beta-cell mass in T2D, such as a low innate beta-cell mass [22], a failed increase in beta-cell mass in response to insulin resistance [2,6] or senescence [23], and/or a progressive beta-cell loss caused by apoptosis [6] or beta-cell dedifferentiation [24]. Recent studies also suggested the involvement of beta-cell ferroptosis, a nonapoptotic regulated cell death that relies on iron-dependent regulated necrosis [25].

The purpose of this review is to discuss recent insights into the molecular mechanisms involved in beta-cell apoptosis in T2D. Indeed, several studies have described a significant increase of beta-cell apoptosis in sections of pancreas as one plausible cause for the decreased beta-cell mass in T2D $[6,10,26,27]$. Supporting this concept, beta-cell apoptosis was also evidenced in isolated human T2D islets [27-29]. As stated above, given the difficulty to assess beta-cell mass in vivo in humans [1], most studies have been performed post mortem or in animal models of T2D, although mouse and human beta-cells may behave differently. Additionally, it should also be stressed that the recourse to isolated pancreatic islets and cultured beta-cells (clonal and primary) is still required to elucidate the molecular mechanisms involved in beta-cell apoptosis due to limited availability of human samples and shortage of technologies. This review will focus on the molecular mechanisms reported to alter beta-cell survival under T2D-prone situations, such as amyloid deposits, lipotoxicity and glucotoxicity. Each situation will be reviewed in separate sections, but it should be borne in mind that in the pathophysiological context they undoubtedly exert synergistic effects. Moreover, if each individual alteration such as endoplasmic reticulum (ER) overload, oxidative stress, inflammation, etc., may not lead to immediate apoptosis in vivo, their cumulative effects will exacerbate the deleterious outcome of each pathway over time (Figure 1). We will also review whether glucagon-like peptide-1 (GLP-1) based therapies can influence beta-cell apoptosis in the context of T2D (Figure 2). 


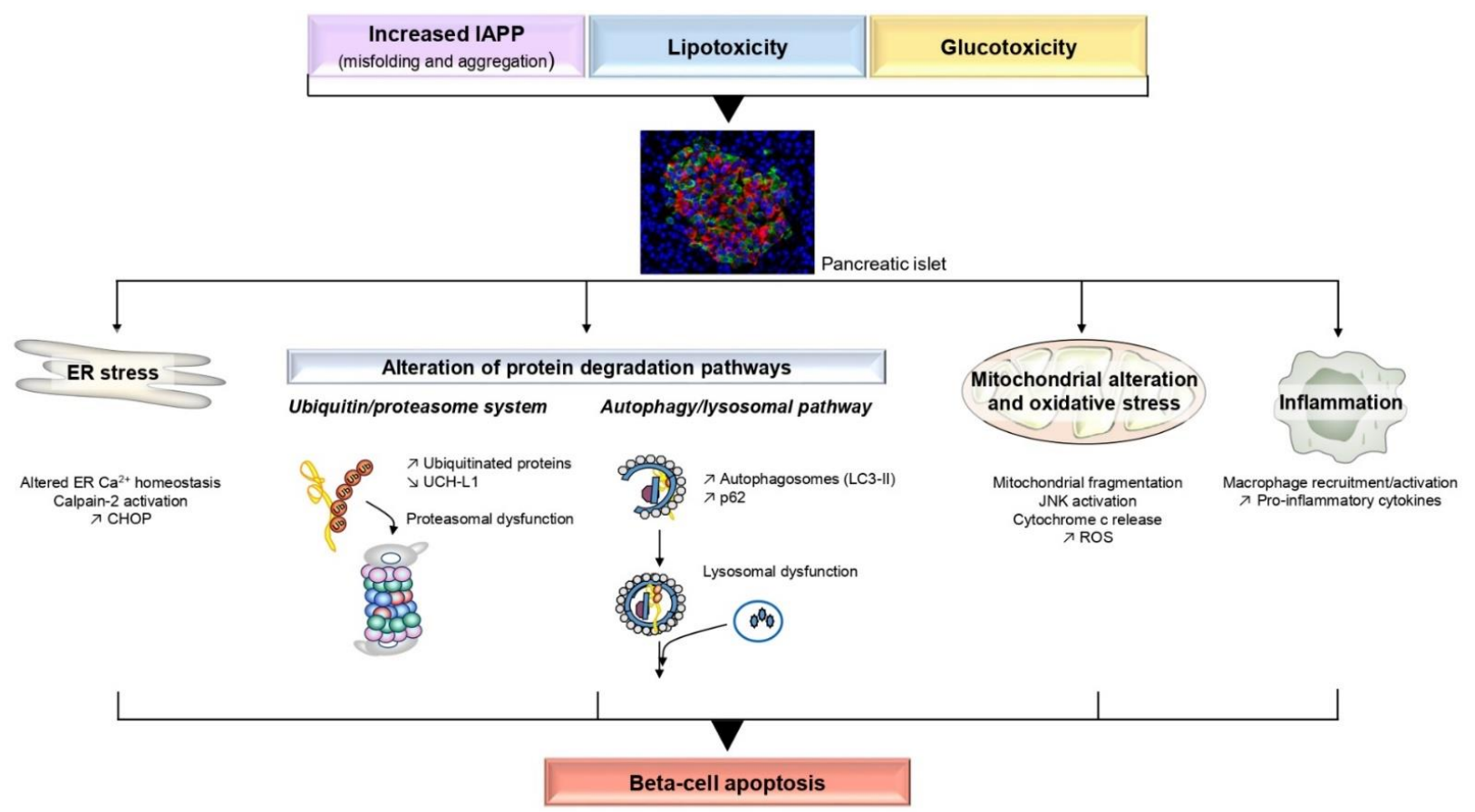

Figure 1. Main mechanisms involved in pancreatic beta-cell apoptosis under T2D-prone situations. Increased islet amyloid polypeptide (IAPP) levels with misfolding and aggregation, lipotoxicity and glucotoxicity are the most investigated causative factors of beta-cell demise. These situations individually elicit stress pathways such as endoplasmic reticulum (ER) stress, mitochondrial/oxidative stress, inflammation, and disrupt the main pathways of protein clearance (ubiquitin-proteasome system and autophagy/lysosomal pathway). The synergistic deleterious effects of these situations as well as the crosstalk between the stress pathways ultimately contribute to beta-cell apoptosis. The immunofluorescence image is a human islet showing beta-cells in red and alpha-cells in green.

\section{Molecular Mechanisms Involved in Beta-Cell Apoptosis}

\subsection{Islet Amyloid Polypeptide}

The islet in T2D is characterized by amyloid deposits derived from islet amyloid polypeptide (IAPP), a protein synthesized and secreted along with insulin by pancreatic beta-cells. Due to an amyloidogenic sequence, IAPP has the propensity to form oligomers and subsequently insoluble fibrils in species at risk to develop diabetes (cats, primates and humans) [22]. Indeed, islet amyloid has frequently been reported in islets from patients with T2D [18,20,30]. Further supporting a role of IAPP in the development of human T2D, a rare missense mutation in the IAPP gene (S20G) that increases its amyloidogenicity [31], is associated with beta-cell deficit and increased risk for T2D [32].

In rodents, IAPP is nonamyloidogenic due to proline substitutions in the amyloidogenic sequence, and these species do not spontaneously develop diabetes [33]. However, overexpression of human IAPP (h-IAPP) in rodent models promotes amyloid deposits, beta-cell dysfunction and apoptosis, consequently leading to reduced beta-cell mass and hyperglycemia $[22,33,34]$, supporting the role of h-IAPP as a contributor to the islet pathology in human T2D. The following paragraphs will focus on the molecular pathways by which amyloidogenic IAPP promotes beta-cell apoptosis.

\subsubsection{ER Stress and Aberrant $\mathrm{Ca}^{2+}$ Release}

ER stress is a well-established feature of T2D [35-37] that is induced by accumulation of misfolded/unfolded proteins in the lumen of the ER. To prevent the deleterious consequences of ER stress, an unfolded protein response (UPR) is engaged by the cells with activation of three main branches of signaling transducers: inositol requiring ER-tonucleus signal kinase 1 (IRE1), PKR-like ER kinase (PERK) and activating transcription factor 6 (ATF6), leading to attenuation of global protein translation, synthesis of folding 
enzymes and ER-associated degradation. Even if ER overload does not necessarily culminate in apoptosis, severe prolonged and unresolved ER stress can shift the balance towards proapoptotic pathway activation.

To face insulin resistance, healthy beta-cells will secrete larger amount of insulin. Since IAPP is coexpressed with insulin, this compensatory production/hypersecretion of insulin and IAPP may exceed the synthesis, folding and trafficking capacity of the ER, eventually leading to the formation of membrane-permeant toxic oligomers [38]. Indeed, toxic oligomers of IAPP have been found associated with ER membranes in beta-cells of individuals with T2D [38], likely contributing to ER stress. Despite one study describing that amyloid formation was not associated with significant increase in ER stress markers [39], most studies performed in transgenic rodent overexpressing h-IAPP, rodent beta-cell lines and human islets/pancreases agree that oligomerization-prone h-IAPP induces ER stressmediated beta-cell apoptosis [35,40-42]. In support of this postulate, deletion of the ER stress marker C/EBP homologous protein (CHOP) was shown to delay beta-cell loss and diabetes onset in h-IAPP transgenic mice [43]. However, deletion of CHOP only partially prevents mice from h-IAPP-induced diabetes [43], suggesting that other molecular mechanisms are involved in h-IAPP toxicity.

Given their membrane-disrupting properties, h-IAPP oligomers may trigger physical changes in the plasma membrane that can be sensed by nonselective ion channels leading to aberrant cytosolic free $\mathrm{Ca}^{2+}$ concentration increases [44,45]. Additionally, since toxic oligomers were found to be associated with intracellular membranes of ER, secretory vesicles and mitochondria in beta-cells of T2D subjects [38], we cannot exclude the possibility that local membrane instability caused by toxic oligomers permits unregulated $\mathrm{Ca}^{2+}$ release from the ER. Indeed, overexpression of h-IAPP, leading to the formation of toxic oligomers, induced apoptosis through increased cytosolic $\mathrm{Ca}^{2+}$ and activation of the $\mathrm{Ca}^{2+}$-dependent proapoptotic protease calpain-2 in INS-1 832/13 beta-cells and isolated human islets [45]. The detection of cleaved alpha-spectrin, a target of calpain-2 and indicator of a compromised cytoskeleton and cellular membranes, in beta-cells from T2D subjects further indicates that calpain may play a key role in the pathophysiology of T2D [45]. In line with this assumption, suppression of calpain activation attenuates h-IAPP-induced beta-cell apoptosis in human islets [45] and in a transgenic mouse model, thereby preventing diabetes onset [46].

\subsubsection{Alteration of Protein Degradation Pathways}

To prevent ER stress-induced apoptosis, cells also promote the elimination of misfolded proteins by the ER-associated degradation. In the cytoplasm, protein quality control is achieved by the ubiquitin-proteasome pathway that involves recognition of dysfunctional/misfolded proteins, their covalent conjugation to ubiquitin and subsequent degradation by the proteasome. Increased expression of amyloidogenic h-IAPP in beta-cells alters the ubiquitin-proteasome system as shown by the accumulation of polyubiquitinated proteins in vitro in clonal beta-cells and isolated human islets, but also in vivo in h-IAPP transgenic rodents $[40,41,47]$. We further demonstrated that this accumulation of ubiquitinated proteins is due to a deficit in ubiquitin C-terminal hydrolase L1 (UCH-L1), a deubiquitinating enzyme that allows ubiquitinated proteins to access the proteasome [47]. Importantly, deficit in UCH-L1 enhances ER stress-induced apoptosis in INS-1 832/13 cells and in vivo in h-IAPP transgenic mouse beta-cells $[47,48]$. The potential involvement of this deleterious mechanism in T2D was evidenced by the presence of polyubiquitinated proteins and decreased UCH-L1 levels in beta-cells of subjects with T2D [47].

The ubiquitin-proteasome system is not the unique pathway involved in the elimination of misfolded proteins. The autophagy/lysosomal pathway (or macroautophagy) also plays a key role to prevent the intracellular accumulation of misfolded/aggregated proteins and damaged organelles. This pathway involves the formation of a double-membrane vesicle, the autophagosome, to surround the material to be degraded. The autophagosomes then fuse with lysosomes in which the sequestered material is degraded by hydrolytic en- 
zymes. Whereas one would have expected that the lysosomal degradation will compensate for the compromised ubiquitin-proteasome system under h-IAPP overexpression, the autophagy pathway is rather impaired in beta-cells overexpressing h-IAPP as demonstrated in vivo in h-IAPP transgenic mice and rats [49]. Consequently, the alteration in lysosomal degradation impairs the clearance of damaged mitochondria through mitophagy [50], inducing oxidative stress and further exacerbating beta-cell ER stress and apoptosis. In addition, the implication of the autophagy in h-IAPP clearance itself shown in isolated human islets and in transgenic mouse models [51-54] contributes to a vicious cycle whereby IAPP reduces lysosomal degradation, which further promotes IAPP overload and toxicity. Further providing evidence of such deleterious mechanism in vivo, a recent article reveals that an autophagy enhancer ameliorated diabetes of h-IAPP transgenic mice through clearance of amyloidogenic oligomers [52]. The potential involvement of autophagy deficits in the decline of beta-cell mass in human T2D has been suggested by the accumulation of autophagic vacuoles [55] and the increased levels of p62, a marker for lysosomal degradation defects, in beta-cells of T2D human islets $[37,53,56]$. It is of note that dead beta-cells with signs of altered autophagy and no major chromatin condensation observed in T2D patients rather reflect an autophagy-associated cell death [55]. This form of programmed cell death morphologically distinct from apoptosis may therefore additionally contribute to beta-cell loss in T2D.

\subsubsection{Oxidative Stress}

Oxidative stress, defined as excessive production and accumulation of reactive oxygen species (ROS), is another mediator of h-IAPP-induced beta-cell apoptosis. In autopsy pancreatic tissues from Japanese patients with T2D, beta-cell loss and islet amyloid are associated with expression of oxidative stress markers [19,37]. In vitro and ex vivo experimental research using rodent beta-cell lines, islets isolated from h-IAPP transgenic mice or human islets showed that h-IAPP/islet amyloid induces oxidative stress, thus contributing to beta-cell apoptosis [50,57-59]. Involvement of oxidative stress in h-IAPP toxicity was further supported by the reduction in h-IAPP-induced beta-cell death following exposure of h-IAPP mouse islets and rat insulinoma RIN-m5F cells to antioxidant or thiol/disulfide reducing agents [59,60]. Mechanistically, overexpression or exogenous addition of h-IAPP activates apoptosis signal-regulating kinase 1 (ASK1), in rodent clonal beta-cells, in beta-cells from h-IAPP transgenic mice and in human islets, leading to c-Jun $\mathrm{N}$-terminal kinase (JNK) activation and beta-cell apoptosis [57,58]. Inhibition of ASK1 was shown to decrease h-IAPP-induced toxicity in RIN-m5F cells and isolated human islets [57]. Interestingly, h-IAPP-induced JNK activation is a critical downstream mediator in both mitochondria-dependent (intrinsic) and death receptor-mediated (extrinsic) beta-cell apoptosis as reported in the h-IAPP transgenic mouse model [58]. Whereas, the involvement of the intrinsic pathway in the cytotoxicity of h-IAPP is consistent with its role in induction of oxidative stress, the activation of the extrinsic pathway suggests that h-IAPP also plays a role in inflammation.

\subsubsection{Inflammation}

Amyloidogenic IAPP toxicity is also linked to islet inflammation and macrophage infiltration, characteristics of islet pathology in T2D [61,62]. Indeed, h-IAPP increases the expression of genes encoding chemokines, macrophage markers, nucleotide-binding domain leucin-rich repeat and pyrin-containing receptor 3 (NLPR3) inflammasome components and proinflammatory cytokines in islets from h-IAPP transgenic mice fed with high fat diet [63]. In line with these results, h-IAPP aggregation triggers activation of the NLRP3 inflammasome, leading to the production of the proinflammatory cytokine interleukin $1 \beta$ (IL1 $\beta$ ) from macrophages and dendritic cells in vitro [64] as well as from resident islet macrophages in h-IAPP transgenic mice $[65,66]$. Whereas the source of islet IL1 $\beta$ remains under consideration (resident macrophages and/or beta-cells themselves), this proinflammatory cytokine is known to induce beta-cell apoptosis. In human islets and 
islets from h-IAPP transgenic mice, IL1 $\beta$ mediates amyloid-induced apoptosis through upregulation of the cell death receptor Fas and caspase-8 activation [67-69]. In addition, amyloid formation reduces the levels of the natural IL1 receptor antagonist (IL1-Ra) in human islets [70], potentially promoting IL1 $\beta$-induced beta-cell death. Consistent with the involvement of receptor-mediated processes in h-IAPP-induced inflammation, the receptor for advanced glycation end products (RAGE) was also reported to interact with toxic h-IAPP intermediates to mediate inflammation and cytoxicity in INS-1 beta-cells and murine primary islets [71]. Prevention of this interaction in vivo inhibited h-IAPP toxicity and ameliorated islet pathology in h-IAPP transgenic mice [71].

\subsection{Lipotoxicity}

Beta-cells can be exposed to high circulating levels of free-fatty acids (FFAs) coming from dietary origin or released by adipose tissue in the context of obesity, a T2D risk factor. Therefore, in vitro studies have suggested that prolonged exposure ( $>12 \mathrm{~h})$ to saturated FFAs alters beta-cell function and survival, a phenomenon that was called lipotoxicity. Nevertheless, whether the increase in FFAs levels in vivo is high enough to damage beta-cells is still hotly debated with strong arguments from both sides [72-74]. Additionally, it remains unclear to what amount and type of lipids beta-cells are indeed exposed in obese and/or T2D patients. This discussion is beyond the scope of our review, so we decided to summarize the available literature on the in vitro mechanisms underlying the toxic effects of FFAs on beta-cells/islets, in order to highlight potential targets involved in apoptosis that might be relevant in vivo. Palmitate is not the only saturated FFA that may target beta-cells in vivo, but it is the most abundant in human plasma, and it was shown to be positively associated with T2D incidence [75]. In addition, palmitate is more toxic than monounsaturated oleate and polyunsaturated linoleate in clonal rodent beta-cells and dispersed human islet cells $[76,77]$. In the following paragraphs, we will therefore focus on the molecular mechanisms involved in beta-cell death under chronic palmitate exposure.

\subsubsection{ER Stress and Aberrant $\mathrm{Ca}^{2+}$ Release}

As demonstrated by the upregulation of a large number of UPR genes in human islets [78] and the activation of PERK and IRE1 branches in INS-1E cells, rat primary beta-cells and human islets [79], an ER stress response is induced by chronic exposure to palmitate. IRE1-induced JNK activation and PERK-induced CHOP contribute to the execution of apoptosis in INS-1E cells [79]. Caspase-12, a prodeath protease located on the outer surface of the ER, is subsequently activated to initiate the proapoptotic cascade caspase under lipotoxic stress [79]. To trigger this deleterious ER response, chronic palmitate depletes ER $\mathrm{Ca}^{2+}$ stores, therefore leading to PERK activation, alteration in ER $\mathrm{Ca}^{2+}$ homeostasis and subsequent ER stress-induced apoptosis in rodent clonal beta-cells and human islets [79-82]. Another consequence of ER Ca ${ }^{2+}$ depletion is the increase in resting cytoplasmic free $\mathrm{Ca}^{2+}$ levels [80], known to initiate a $\mathrm{Ca}^{2+}$-dependent beta-cell death pathway along with the activation of calpain-2 as observed in INS-1 832/13 cells treated with palmitate and high glucose, but also in islets from diabetic $d b / d b$ mice [82].

Chronic palmitate not only disrupts protein folding capacity of the ER, but also induces ER protein overload. Palmitate alters ER lipid rafts distribution [83] and induces aberrant protein palmitoylation [84], therefore reducing ER-to-Golgi protein trafficking and contributing to beta-cell lipoapotosis [85]. In line with these data, a recent combined human islet transcriptomic and INS-1E cell proteomic study revealed that palmitate modifies genes involved in ER function, ER-to-Golgi transport and ER stress pathway in beta-cells [86]. Initiation of ER stress by palmitate also activates the intrinsic mitochondrial pathway of apoptosis in clonal and primary rat beta-cells, pointing to an ER stress-mitochondrial cross talk involved in lipotoxic beta-cell apoptosis [87]. 


\subsubsection{Mitochondrial Alterations}

Palmitate-induced beta-cell apoptosis was shown to be mediated by the intrinsic mitochondrial pathway as demonstrated by the translocation of the proapoptotic component $\mathrm{Bax}$ from the cytosol to the mitochondria, and the subsequent cytochrome $\mathrm{c}$ release from the mitochondria to form the apoptosome involved in caspase- 9 and -3 activation in INS-1E cells [87]. Contributing to the induction of this mitochondrial pathway of apoptosis, in vitro exposure to palmitate also reduces the expression of the antiapoptotic components $\mathrm{Bcl}-\mathrm{xl}$ and Bcl-2 [87,88], and induces the expression of proapoptotic members death protein 5 (DP5) [87] and p53-upregulated modulator of apoptosis (PUMA) in clonal, primary rat and human beta-cells $[87,88]$. Supporting their role in palmitate-induced beta-cell apoptosis, knockdown of either DP5 or PUMA reduces apoptosis in rat and human beta-cells and protects mice from high fat diet-induced diabetes [87]. Palmitate further contributes to beta-cell apoptosis through disruption of the mitochondrial network as illustrated by the punctuated/fragmented mitochondria morphology in rodent clonal beta-cells and human islets $[78,87,89,90]$. In addition, through generation of excess nitric oxide (NO), palmitate causes mitochondrial DNA damage-induced apoptosis in INS-1 cells [91]. Palmitate was also reported to trigger ROS production from diverse sources including the mitochondrial electron transport chain [92], peroxisomes [93], or due to NADPH oxidase activation [94]. A recent transcriptomic/proteomic profiling using INS-1E cells and isolated human islet data further suggested that palmitate may elicit an oxidative stress response in beta-cells [86].

\subsubsection{Autophagy and Ubiquitin-Proteasome System Impairment}

Palmitate was firstly suggested to stimulate autophagy in INS-1 cells [95], but other studies revealed that exposure to palmitate rather impairs lysosomal degradation in pancreatic beta-cells [78,96-98]. In human islets chronically exposed to palmitate, beta-cells present a massive increase in autophagic vacuoles and autophagosomes associated with decreased lysosomal-associated membrane protein 2 (LAMP2) and cell death, similar to T2D islets [55]. These observations suggest that palmitate alters autophagic removal of these structures. Indeed, elevated levels of palmitate were shown to increase autophagosome numbers $[78,96,97,99-101]$ but alter autophagic flux in clonal beta-cells and human islets [78,96-98]. Among the mechanisms involved in palmitate-induced autophagic flux impairment, defect in lysosomal acidification and function [96,98], activation of mammalian target of rapamycin complex 1 (mTORC1), an inhibitor of autophagy [97], and ER stress-induced JNK activation [99] were proposed to contribute to this lipotoxic alteration. In addition, RNA-sequencing analysis of palmitate-treated human islets reveals a decrease in autophagy-related and lysosomal function-related genes that may affect autophagosome-lysosome fusion [78]. The link between palmitate-induced autophagy alteration and beta-cell apoptosis was evidenced by the use of autophagy enhancing drugs such as rapamycin and carbamazepine. Despite some controversies regarding the role of palmitate on autophagy modulation (inhibition or activation), all studies unanimously reported that stimulation of autophagy restores autophagic flux and decreases palmitateinduced apoptosis in rodent beta-cells and human islets [78,96,97,101-103], while blocking autophagy exacerbates beta-cell lipoapoptosis [102]. Supporting the relevance of these findings in human T2D, rapamycin was shown to restore autophagic flux and to alleviate ER stress and beta-cell death in human T2D islets [102], further pointing to a protective role of autophagy in the maintenance of beta-cell integrity.

The role of FFAs on the ubiquitin-proteasome system has been less investigated. However, studies reported that palmitate disrupts the proteasome function as demonstrated by the altered expression of genes associated with proteasome activity in human islets [78] and the accumulation of ubiquitinated proteins in the MIN6 beta-cell line, isolated mouse and human islets, similar to what is observed in pancreatic sections from mice fed a high fat diet and from obese human donors [88]. Under these conditions, activation of the pro- 
teasome decreases ubiquitinated proteins and prevents the proapoptotic pathway induced by palmitate in MIN6 cells [88].

\subsubsection{Inflammation}

Supporting a role of lipotoxicity in islet inflammation, several studies revealed that exposure of human islets to palmitate promotes the expression of proinflammatory cytokines and chemokines $[104,105]$. Whereas this IL1 $\beta$-dependent induction of cytokines and chemokines can be prevented by IL1R antagonism [104,105], blockage of IL1 $\beta$ signaling does not protect human islets from lipotoxicity-induced beta-cell death [105], suggesting that palmitate-induced mild inflammation may not be involved in beta-cell apoptosis. In addition, Wali et al. demonstrated that palmitate-induced islet cell death is not dependent on the activation of the NLRP3 inflammasome [106]. Recent studies however revisited the role of palmitate-induced inflammation in beta-cell apoptosis. Indeed, Hu et al. identified the stimulator of interferon genes-interferon regulatory factor 3 (STING-IRF3) as a novel signaling pathway involved in lipotoxicity-induced beta-cell inflammation and apoptosis using INS-1 cells and islets from $d b / d b$ mice [107]. Furthermore, palmitate exposure also triggers secretion of a member of damage-associated molecular patterns (DAMPs) by isolated human islets to promote macrophage infiltration of the islets, further driving islet inflammation and beta-cell apoptosis [108]. Significant increase in the expression of this specific DAMPs molecule was detected in islets of $d b / d b$ mice, highlighting the potential relevance of this mechanism in vivo [108].

\subsection{Glucotoxicity and Glucolipotoxicity}

Once the pathogenesis of diabetes is established, the sustained elevated levels of glucose seen in individuals with T2D may ultimately exacerbate the loss of functional betacells, and this concept has been termed "glucotoxicity" [109]. Supporting this assumption, high glucose exposure has been shown to trigger beta-cell apoptosis in cultured human islets [110-112]. In the course of obesity-associated T2D, the combined excess of glucose and lipids may synergize to cause a faster and severe progression of beta-cell deficit, a phenomenon called "glucolipotoxicity" [113-116], albeit debated [74]. In this section, we will report recent mechanisms involved in glucotoxicity-induced beta-cell apoptosis as well as the deleterious effects of glucolipotoxicity.

\subsubsection{ER Stress and Aberrant $\mathrm{Ca}^{2+}$ Release}

Chronic hyperglycemia was shown to perturb ER homeostasis and to induce ER stress in pancreatic beta-cells. Indeed, prolonged exposure to high glucose leads to $\mathrm{Ca}^{2+}$ efflux from the ER to the cytosol, a process ultimately involved in beta-cell death [82]. This deleterious $\mathrm{Ca}^{2+}$ efflux from the ER was explained by the downregulation of the sarco/endoplasmic reticulum $\mathrm{Ca}^{2+}$-ATPase $2 \mathrm{~b}$ (SERCA2b) pump as observed in INS-1 $832 / 13$ cells treated with chronic high glucose, but also in islets from $d b / d b$ mice and human islets from subjects with T2D [82]. Importantly, the ER $\mathrm{Ca}^{2+}$ depletion is worsened in INS-1 832/13 beta-cells exposed to glucolipotoxic conditions [82]. Recently, a phenotypic screen conducted to identify molecules that protect beta-cells further points to $\mathrm{Ca}^{2+}$ overload as a key mechanism of glucolipotoxicity-induced apoptosis in INS-1E cells, rat and human islets [117]. In addition, gluco(lipo)toxicity has been shown to induce ER stress-mediated beta-cell apoptosis through the induction of the PERK-dependent proapoptotic factor $\mathrm{CHOP}$ in mouse islets [118]. mTORC1 also appears as an important transducer of ER stress response under glucolipotoxicity as demonstrated by its implication in the activation of IRE1 $\alpha$-JNK pathway [119]. Glucotoxicity-mediated ER stress further induces activation of apoptosis-initiating Bcl-2 homology domain 3 (BH3) proteins such as Bim and PUMA in mouse islets [118], pointing to the reciprocal interplay between ER stress and mitochondrial pathway of apoptosis under nutrient stress conditions. 


\subsubsection{Oxidative Stress and Mitochondrial Dysfunction}

Exposure to high levels of glucose (in combination with FFAs) has been shown to affect beta-cell viability by inducing oxidative stress and mitochondrial apoptosis $[116,120]$. Indeed, inhibition of oxidative stress protects clonal beta-cells, mouse islets and human islets against the adverse effects of glucotoxicity $[118,120]$. Recently, altered iron metabolism has been identified as a novel mechanism relaying gluco(lipo)toxicity to cytosolic ROS production, mitochondrial dysfunction and beta-cell apoptosis in isolated mouse islets, but also in vivo in a transgenic mouse model with beta-specific knockout of an iron transporter [121]. Supporting the involvement of mitochondrial dysfunction in glucotoxicity-induced betacell demise, a global downregulation of mtDNA-encoded respiratory chain subunits has been shown in human islets chronically exposed to elevated glucose levels [110]. This alteration may lead to altered respiratory activity and increased susceptibility of beta-cells to apoptosis [110]. Furthermore, elevated glucose (and FFAs) alters mitochondrial dynamics in INS-1 cells [90] and in islets from diabetic Goto Kakizaki (GK) rats [89,122], whereas its preservation protects INS-1 beta-cells from glucolipotoxicity-induced mitochondrial fragmentation and apoptosis [90].

\subsubsection{Autophagy and Ubiquitin-Proteasome System Impairment}

Chronic exposure to elevated glucose has been shown to favor accumulation of ubiquitinated proteins in clonal rat beta-cells and human islets [123,124]. Large aggregates of ubiquitinated proteins in beta-cells were also observed on Zucker diabetic fatty rat pancreatic sections [124]. These observations suggest that the degradation systems removing such modified proteins (autophagy and/or proteasome) are dysfunctional in beta-cells exposed to glucotoxic conditions. In Broca et al., accumulation of ubiquitinated proteins was attributed to a decrease in proteasomal function as shown in high glucosetreated INS-1E cells, human islets and hyperglycemic GK rat islets [123]. The alteration in proteasomal activity was shown to be involved in ER stress induction and subsequent beta-cell apoptosis in INS-1E cells and human islets [123]. In contrast, it was also reported that although the proteasome is recruited to ubiquitinated protein aggregates in clonal beta-cells exposed to high glucose, autophagy is rather involved in mediating their clearance [124], therefore suggesting an alteration of beta-cell autophagic clearance under glucotoxic treatment. Only few studies investigated the role of glucotoxicity on beta-cell autophagy. Glucotoxicity was shown to positively regulate autophagy via PTEN-induced putative kinase 1 (PINK1) in INS-1 and rat beta-cells [125] with an increased number of autophagosomes detected in human islets [110], but it was also suggested that glucotoxicity alters lysosomal degradation in human islets [97]. Most studies investigated the effects of glucolipotoxicity and revealed that whereas glucose and palmitate synergize to increase autophagosome formation $[56,96,97,126]$, this combination also impairs autophagic flux through lysosomal dysfunction in clonal beta-cells, mouse and human islets $[56,96,97]$. This defect occurring downstream of ER stress leads to accumulation of defective lysosomes and subsequent release of hydrolytic enzymes such as cathepsin D through lysosomal membrane permeability [56]. This release of cathepsin D into the cytoplasm, observed in treated INS-1E cells, mouse islets and pancreatic sections from T2D subjects, is involved in glucolipotoxicity-induced beta-cell death [56]. To further support the involvement of defective autophagic clearance as a mediator of glucolipotoxicity, stimulation of autophagy with rapamycin was shown to protect rodent clonal beta-cells from glucose and lipid excess-induced apoptosis $[97,126]$.

\subsubsection{Inflammation}

Whereas intra-islet IL1 $\beta$ production was suggested to be a toxic response to high glucose exposure in human islets $[127,128]$, other studies failed to demonstrate any increase in IL1 $\beta$ expression in human beta-cells exposed to glucotoxicity $[105,106,129]$. Furthermore, neither IL1 $\beta$ production nor activation of the NLRP3 inflammasome complex seem to mediate islet cell death in response to glucotoxicity or glucolipotoxicity [106,129-131]. Linking 
glucotoxicity to islet inflammation, a recent study, however, reported that high glucose concentrations trigger secretion of a signaling molecule (DAMPs) from pancreatic human islets, promoting macrophage infiltration of the islets, further driving islet inflammation and beta-cell apoptosis [108]. This cascade of events is exacerbated under a combination of glucose and lipids [108]. Attraction of circulating immune cells involved in local islet inflammation and beta-cell death may also be mediated by gluco(lipo)toxic activation of the transcription factors nuclear factor-kappa $\mathrm{B}(\mathrm{NF} \kappa \mathrm{B})$ and signal transducer and activator of transcription 1 (STAT1) through tumor necrosis factor receptor 5 (TNFR5) induction, as shown in INS-1 cells, human islets, and islets from high fat-fed mice [132].

\subsubsection{Epigenetic Mechanisms and Nuclear Events}

Epigenetic mechanisms may also contribute to gluco(lipo)toxicity-induced beta-cell apoptosis by modulating gene expression through chromatin modification and/or noncoding RNAs. Indeed, Li et al. demonstrated that the microRNAs (miRNAs) miR-375, miR-30a and miR-34a are increased in INS-1 cells and pancreatic islets exposed to high glucose levels, as well as in islets from diabetic GK rats [133]. miRNAs are endogenous non-coding RNAs known to regulate gene expression by binding to the $3^{\prime} \mathrm{UTR}$ of their target mRNAs resulting in their degradation and/or translational inhibition. In this study, glucotoxicity-induced miR-375, miR-30a and miR-34a are involved in the inactivation of Notch1 pathway, resulting in INS-1 cell apoptosis [133]. Using a miRNA microarray analysis, another study identified a set of differentially expressed miRNAs in human islets exposed to glucolipotoxic conditions [134]. Among them, miR-299-5p was shown to be downregulated and this was revealed as a key mediator of glucolipotoxicity-induced beta-cell apoptosis in human islets [134]. Regarding the factors involved in chromatin remodeling, the histone acetyl-transferase p300 was shown to be diminished in clonal beta-cells and human islets exposed to gluco/lipotoxicity as well as in beta-cells of human T2D donors [135]. This study further demonstrates that alteration of p300 levels and activity plays a key role in mediating apoptosis in INS-1E cells and isolated mouse islets [135]. The transcription factor cAMP-responsive element-binding protein (CREB) is another key component of the transcriptional beta-cell machinery promoting cell survival. We demonstrated that the degradation of CREB by the ubiquitin-proteasome system is a mechanism subserving glucotoxicity-induced beta-cell death in rodent beta-cells and human islets [136]. Finally, induction of the abovementioned deleterious mechanisms in gluco(lipo)toxic INS-1 832/13 cells, rodent and human islets culminates in activation of executioner caspases (-3 and -6$)$ that are involved in the degradation of nuclear lamins, components of the lamina in the nuclear envelope $[137,138]$. As a consequence of lamin degradation, chromatin condensation and collapse of nuclear envelope under glucotoxicity appear as additional events involved in beta-cell demise [137,138].

\section{Molecular Mechanisms Induced by GLP-1 to Protect Beta-Cells from Apoptosis}

Oral glucose induces a greater stimulation of insulin secretion than intravenous glucose administration. This is called the incretin effect [139] and is caused by the release of GLP-1 and glucose-dependent insulinotropic polypeptide (GIP) from the gut by L and $\mathrm{K}$ cells, respectively. GIP has a poor insulinotropic efficacy in T2D, thus incretin basedtherapies have been focused on GLP-1. Moreover, GLP-1 based therapies have positive impact in promoting weight loss [140] and present low risk of hypoglycemia as they induce insulin secretion in the presence of elevated glucose concentrations. GLP-1 has a short halflife (1-2 $\mathrm{min})$ as it is rapidly degraded in the circulation by a serine exopeptidase dipeptidyl peptidase 4 (DPP-4) [139]. Consequently GLP-1 receptor agonist (GLP-1RA) therapies have been developed in generating either stable derivatives of GLP-1 with prolonged action resistant to DPP-4 (liraglutide, dulaglutide, semaglutide, lixisenatide) [140], or derivatives of exendin-4 (exenatide, lixisenatide) [140]. Instead, another strategy consists of using inhibitors of DPP-4 (iDPP-4) activity to preserve the endogenous production of GLP-1 [141]. 
At the molecular level, GLP-1 binds to its receptor (GLP-1R) belonging to the Gprotein coupled receptor (GPCR) family, which is known to be positively coupled to cAMP production, albeit a coupling to $\mathrm{Gq}$ has also been reported [142,143]. The intracellular increase in cAMP production activates protein kinase A (PKA) and cAMPactivated guanine nucleotide exchange factors that target Ras-like GTPases 2 (EPAC2), which in turn mediate changes in ion-channel activity leading to an increase in cytosolic $\mathrm{Ca}^{2+}$ concentration, but also exert a direct action at the level of the exocytosis machinery [144] (Figure 2). These events enhance the stimulation of insulin secretion in a glucose-dependent manner. The GLP-1R is also known to recruit scaffold proteins such as beta-arrestins (ARRBs) $[145,146]$ that may activate extracellular signal-related kinases 1 and $2($ ERK1/2) [147,148] or c-SRC [149], which are known to be involved in beta-cell survival. Of note, ERK1/2 are also activated by GLP-1 independently of ARRBs in a PKA dependent manner [147].

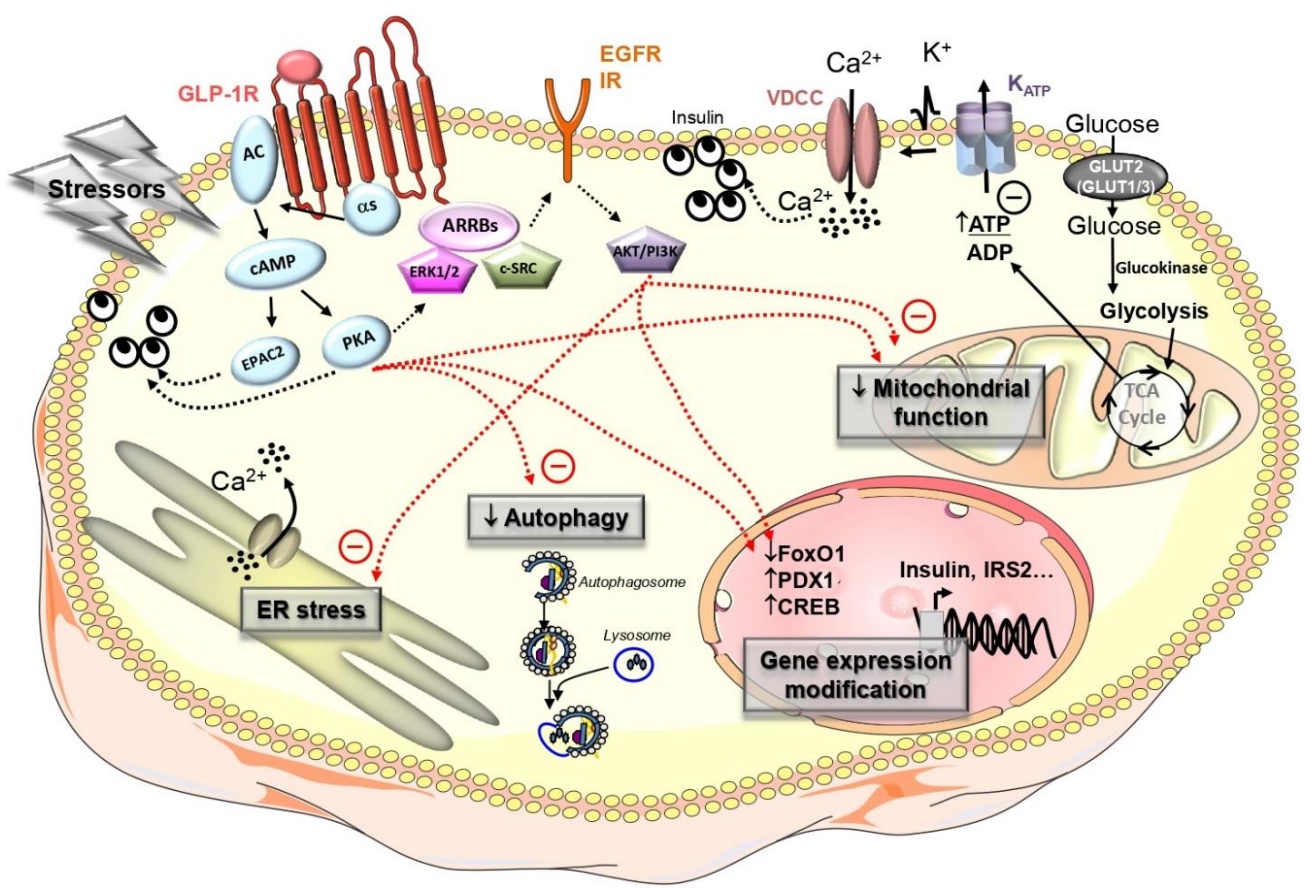

Figure 2. Main molecular mechanisms induced by glucagon-like peptide-1 (GLP-1) to protect betacells from apoptosis. Beta-cell stressors (such as increased IAPP, gluco- and/or lipotoxicity) may trigger ER stress, alter mitochondrial function and/or the autophagic flux and modify gene expression. GLP-1 and GLP-1RA have been reported to protect beta-cells by alleviating these deleterious effects.

\subsection{GLP-1RA Alleviates Beta-Cell Apoptosis Induced by Diabetogenic Conditions or in T2D}

GLP-1R activation triggers the transcription of genes involved in proliferation, or that display antiapoptotic and/or anti-inflammatory activities in beta-cells, suggesting that GLP-1 promotes beta-cell survival and regulates beta-cell mass [150]. However, whereas a treatment with long lasting analogues such as liraglutide or dulaglutide are able to promote pancreatic beta-cell proliferation in diabetic $d b / d b$ mice $[151,152]$, in high-fat-fed and streptozotocin-induced [153] or alloxan-induced [154] mouse model of T2D, it is well accepted that adult human beta-cells have a limited capacity to proliferate [155]. On the contrary, many studies have identified in rodent and human that GLP-1RA alleviate beta-cell apoptosis [151,156-159] induced by several stressors such as gluco/lipotoxicity [160-163], which may trigger oxidative [164] and ER stress [162,165], or by cytokines [166-169]. A reduced beta-cell apoptosis was also observed in diabetic $d b / d b[152]$ and Akita $[170,171]$ mice or prediabetic GK rats [172] chronically treated with GLP1-RA. Unlike GLP-1-induced insulin secretion, its role as a pro survival molecule is far from a consensus, and pleiotropic effects have been reported. Indeed, multiple signal- 
ing pathways and the regulation of various genes have been described. Therefore, our knowledge regarding the molecular mechanisms involved is unclear. For instance, depending on studies and models, GLP-1RA were shown to protect beta-cells from apoptosis through PKA and phosphoinositide 3-kinase (PI3K)-AKT-dependent pathways partly via the inhibition of ER stress $[162,165,171,173]$ by increasing immunoglobulin heavy-chain binding protein (BiP) and JunB [162] or by blocking the induction of sterol regulatory element-binding protein 1 (SREBP1c) and $\mathrm{C} / \mathrm{EBPb}$ transcription factors [174]. Independently of ER stress, PKA and PI3K-AKT-dependent pathways were shown to be involved in suppression of Forkhead box O1 (FoxO1) $[160,175,176]$, the restoration of pancreatic and duodenal homeobox 1 (PDX1) [176,177] via mammalian sterile 20-like kinase 1 (Mst1) inactivation [161], inactivation of NADPH oxidase 2 (NOX2) [163] or improved mitochondrial function [161] by suppressing sustained AMP-activated protein kinase (AMPK) hyperactivation [178]. Exendin-4 also reduced oxidative damage and apoptosis through $\mathrm{Ca}^{2+}$-independent phospholipase A2 [179], or preserved proteasome activity from the deleterious effects of glucotoxicity [123] in clonal beta-cell lines.

Other signaling that is known to be involved in beta-cell survival is also improved upon GLP-1R treatment such as the insulin signaling [180] or the activation of the transcription factor CREB $[181,182]$ leading to the expression of the insulin receptor substrate 2 (IRS-2) [181,182]. Finally, GLP-1 was shown to trigger the phosphorylation of Bad at specific Ser sites leading to its inactivation, via SAD-A, a serine/threonine protein kinase of the AMPK subfamily [183] or via ERK1/2- phosphorylated p90 ribosomal S6 kinase (p90RSK) activation [147]. On the contrary, a prolonged treatment with GLP-1 did not retain protective effect probably because of the increased ER stress [160].

Autophagy, which prevents beta-cell injury and death by protecting against ER stress, inflammation and/or oxidative stress, was shown to be affected by GLP1-RA. Exendin-4 was primarily reported to improve beta-cell function and survival without modulating the autophagic flux [184]. This was demonstrated by only measuring p62 expression in diabetic $d b / d b$ mice [184]. Nevertheless, with the development of new techniques to monitor the autophagic flux, it is now agreed that GLP-1RA may indeed modulate autophagy in beta-cells [184]. In glucolipotoxic beta-cells (clonal INS-1E cells and human islets) that showed increased apoptosis, the number of autophagosomes was shown to be increased, demonstrating a blockade of the autophagic flux [56]. Interestingly, treatment of beta-cells and/or animals with exendin-4 [56] or liraglutide [153,185-187] rescued lysosomal function and autophagic flux in both lipotoxic and glucolipotoxic conditions leading to a protective effect on beta-cells, and suggesting that stimulation of the autophagic flux by GLP-1 is critical for its protective effects [188].

The mechanisms underlying the impact of GLP-1RA on both autophagy and lysosomal function are not yet elucidated, but several pathways have been explored. It has been recently reported in INS-1 cells that liraglutide ameliorated the injury triggered by lipotoxic conditions through the upregulation of autophagy mediated by FoxO1 [187], or throughout the upregulation of mesencephalic astrocyte derived neurotrophic factor (MANF) in MIN6 cells [189], thus protecting cells from ER stress. It has also been reported that GLP-1 may protect beta-cells from glucotoxicity through enhancing autophagy by AMPK inhibition in INS-1 cells [190]. GLP-1-induced protection against apoptosis through the autophagic flux in human beta-cells still need to be fully explored.

Only a limited number of studies have investigated the potential impact of GLP1RA on IAPP toxicity. Exendin-4 alleviated h-IAPP-induced apoptosis in MIN6 [191] and in INS-1E [192] beta-cell lines, in islets from h-IAPP transgenic mice [193] or in human islets $[194,195]$. The protection was not associated with a reduced formation of h-IAPP deposits [192], but with increased levels of AKT phosphorylation [192-195]. Several mechanisms downstream AKT phosphorylation have been reported such as reduced IL1 $\beta$ immunoreactivity and release [194], the enhancement of pro h-IAPP processing [195], translocation of PDX-1 in the nucleus [192] and improved mitochondrial function [192]. A reduced JNK activation has not always been noticed [192,195], and exendin-4 protection 
from h-IAPP toxicity does not seem to alleviate ER stress in INS-1E cells [192]. Finally, an improvement of the autophagic flux by exendin- 4 was reported in MIN6 cells overexpressing h-IAPP [191].

\section{2. iDPP-4 Alleviates Beta-Cell Apoptosis Induced by Diabetogenic Conditions}

Although the impact on weight loss is less pronounced than that of GLP-1RA, inhibition of DPP-4 activity is another potent strategy for preserving both GLP-1 and GIP endogenous production, and therefore enhancing incretin-induced insulin secretion in T2D [141]. Few studies in vivo have investigated the impact of DPP-4 inhibition on beta-cell survival [196-202]. In Zucker diabetic rats, the plasma levels of GLP-1 were increased upon alogliptin treatment, and beta-cell survival was improved through CREB activation, and restoration of Bcl-2 and IRS-2 expression [196]. Vildagliptin reduced beta-cell apoptosis in a mouse model of diabetes (KK-Ay-TaJcl) [197] and in $d b / d b$ [199] mice, and this was associated with decreased ER [197,199] and oxidative stress [197]. Moreover, vildagliptin was also reported to protect beta-cells from inflammation in advanced-aged diet-induced obesity mouse model [200], while a treatment with another iDPP-4, MK-626, improved the autophagic flux in high fat diet-induced obese mice [201].

In addition to preserving GLP-1 secreted by the gut, recent studies have reported that inhibiting DPP-4 may also protect GLP-1 released locally by islets [203-206]. Indeed, DPP-4 is expressed in rodent and human islets [205,207-210] and GLP-1 was reported to be expressed [205,211,212] and released [205,211,212] by islet alpha-cells upon glucose [211], arginine [211], GPR142 activation [213] or GIP stimulation [214]. Intra-islet GLP-1 makes a significant contribution to islet adaptation, particularly expansion of beta-cell mass to face insulin resistance $[158,215]$ or adaptation in pregnancy [216] in mice. Moreover, intra islet GLP-1 was shown to reduce apoptosis triggered by lipotoxicity [158] and glucolipotoxicity [213] in rodent beta-cells, whereas blocking GLP-1R signaling in beta-cells with exendin-(9-39) decreased cell viability and increased cell apoptosis via PDX1 inhibition [158]. Inhibiting DPP-4 activity in human beta-cells protected against gluco- [203], lipo- [203] and cytokine- [203,204] induced toxicity by reducing cytokine production and secretion from islets [203] and NFKB1 expression [204]. A reduction of oxidative stress was also involved [203]. Most importantly, it also reduced apoptosis in islets from T2D donors, suggesting that inhibiting DPP-4, besides playing a role in incretin effects, directly affects beta-cell survival [204]. Nevertheless, it should be stressed that in T2D islets the proportion of alpha-cells expressing GLP-1 is increased [205] while DPP-4 expression [204,210] and activity [208] are reduced, leading to an increased secretion of GLP-1 [211]. Therefore, a protective role of iDPP4 in preserving intra islet GLP-1 needs to be further addressed to unequivocally determine its relevance in T2D.

\section{Conclusions and Perspectives}

This review relates the molecular mechanisms involved in beta-cell apoptosis. As stated above for clarity, we independently described the stress pathways involved, but it has to be considered that crosstalk between these pathways may occur at different levels to further exacerbate beta-cell death (Figure 1). Moreover, even though amyloid deposits, lipotoxicity and glucotoxicity are the "most investigated" causative factors of beta-cell demise, hostile environmental context may also superimpose deleterious mechanisms to further accelerate the progression towards overt T2D. Indeed, a new area of research points to the detrimental consequences of altered circadian rhythms/sleep deprivation or exposure to pollutants on beta-cell survival [217-219].

It should also be stressed that mainly in vitro or ex vivo molecular mechanisms involved in beta-cell apoptosis were reported as stated in the introduction. Although studies in human islets have been described, the relevance of these mechanisms remains to be proven in T2D. In particular, whether "lipotoxicity" has a significant deleterious effect on beta-cells in vivo. Another key point that is still unknown, is whether GLP-1RA-based therapies in T2D patients participate in the protection and maintenance of the beta-cell 
mass in vivo. This question is unresolved because we are still lacking technologies to assess in $3 \mathrm{D}$ the real beta-cell mass in vivo in humans.

Finally, whereas the protective mechanisms of GLP-1R based therapies have been studied, only few studies have investigated beta-cell protection induced by the other incretin GIP [220], and its relevance in human islets remains to be established. This is a critical question that will undoubtedly be addressed in futures studies. Indeed, although GLP-1 and GIP have some overlapping functionality, their combined use (dual agonist also called twincretins) leads to synergistic effects on diabetes and related metabolic disease [221-223]. Therefore, development of dual agonists and elucidation of their potential role on beta-cell mass preservation represent a considerable interest to improve current GLP-1R-based therapies in T2D.

Author Contributions: S.C., M.A.R., G.B.; writing—original draft preparation, S.C., M.A.R., G.B.; writing-review and editing. All authors have read and agreed to the published version of the manuscript.

Funding: This work was supported by the Centre National de la Recherche Scientifique (CNRS), Institut National de la Santé et de la Recherche (INSERM), Univ of Montpellier and research allocations to S.C. and M.A.R. obtained from the "Société Francophone du Diabète" (SFD, Paris, France).

Acknowledgments: We apologize to the many authors whose work could not be cited owing to space restrictions.

Conflicts of Interest: The authors declare no conflict of interest.

\section{References}

1. Chen, C.; Cohrs, C.M.; Stertmann, J.; Bozsak, R.; Speier, S. Human beta cell mass and function in diabetes: Recent advances in knowledge and technologies to understand disease pathogenesis. Mol. Metab. 2017, 6, 943-957. [CrossRef]

2. Mezza, T.; Cinti, F.; Cefalo, C.M.A.; Pontecorvi, A.; Kulkarni, R.N.; Giaccari, A. beta-Cell Fate in Human Insulin Resistance and Type 2 Diabetes: A Perspective on Islet Plasticity. Diabetes 2019, 68, 1121-1129. [CrossRef] [PubMed]

3. Polonsky, K.S.; Given, B.D.; Van Cauter, E. Twenty-four-hour profiles and pulsatile patterns of insulin secretion in normal and obese subjects. J. Clin. Investig. 1988, 81, 442-448. [CrossRef] [PubMed]

4. Camastra, S.; Manco, M.; Mari, A.; Baldi, S.; Gastaldelli, A.; Greco, A.V.; Mingrone, G.; Ferrannini, E. beta-cell function in morbidly obese subjects during free living: Long-term effects of weight loss. Diabetes 2005, 54, 2382-2389. [CrossRef] [PubMed]

5. Ferrannini, E.; Natali, A.; Bell, P.; Cavallo-Perin, P.; Lalic, N.; Mingrone, G. Insulin resistance and hypersecretion in obesity. European Group for the Study of Insulin Resistance (EGIR). J. Clin. Investig. 1997, 100, 1166-1173. [CrossRef] [PubMed]

6. Butler, A.E.; Janson, J.; Bonner-Weir, S.; Ritzel, R.; Rizza, R.A.; Butler, P.C. Beta-cell deficit and increased beta-cell apoptosis in humans with type 2 diabetes. Diabetes 2003, 52, 102-110. [CrossRef]

7. Rahier, J.; Guiot, Y.; Goebbels, R.M.; Sempoux, C.; Henquin, J.C. Pancreatic beta-cell mass in European subjects with type 2 diabetes. Diabetes Obes. Metab. 2008, 10 (Suppl. S4), 32-42. [CrossRef]

8. Saisho, Y.; Butler, A.E.; Manesso, E.; Elashoff, D.; Rizza, R.A.; Butler, P.C. Beta-cell mass and turnover in humans: Effects of obesity and aging. Diabetes Care 2013, 36, 111-117. [CrossRef]

9. Mezza, T.; Muscogiuri, G.; Sorice, G.P.; Clemente, G.; Hu, J.; Pontecorvi, A.; Holst, J.J.; Giaccari, A.; Kulkarni, R.N. Insulin resistance alters islet morphology in nondiabetic humans. Diabetes 2014, 63, 994-1007. [CrossRef] [PubMed]

10. Yoneda, S.; Uno, S.; Iwahashi, H.; Fujita, Y.; Yoshikawa, A.; Kozawa, J.; Okita, K.; Takiuchi, D.; Eguchi, H.; Nagano, H.; et al. Predominance of beta-cell neogenesis rather than replication in humans with an impaired glucose tolerance and newly diagnosed diabetes. J. Clin. Endocrinol. Metab. 2013, 98, 2053-2061. [CrossRef]

11. Cigliola, V.; Thorel, F.; Chera, S.; Herrera, P.L. Stress-induced adaptive islet cell identity changes. Diabetes Obes. Metab. 2016, 18 (Suppl. S1), 87-96. [CrossRef]

12. Davis, S.N.; Piatti, P.M.; Monti, L.; Brown, M.D.; Branch, W.; Hales, C.N.; Alberti, K.G. Proinsulin and insulin concentrations following intravenous glucose challenges in normal, obese, and non-insulin-dependent diabetic subjects. Metabolism 1993, 42, 30-35. [CrossRef]

13. Lang, D.A.; Matthews, D.R.; Burnett, M.; Turner, R.C. Brief, irregular oscillations of basal plasma insulin and glucose concentrations in diabetic man. Diabetes 1981, 30, 435-439. [CrossRef] [PubMed]

14. O'Rahilly, S.; Turner, R.C.; Matthews, D.R. Impaired pulsatile secretion of insulin in relatives of patients with non-insulindependent diabetes. N. Engl. J. Med. 1988, 318, 1225-1230. [CrossRef]

15. U.K. Prospective Diabetes Study Group. U.K. prospective diabetes study 16: Overview of 6 years' therapy of type II diabetes: A progressive disease. Diabetes 1995, 44, 1249-1258. [CrossRef]

16. Kendall, D.M.; Sutherland, D.E.; Najarian, J.S.; Goetz, F.C.; Robertson, R.P. Effects of hemipancreatectomy on insulin secretion and glucose tolerance in healthy humans. N. Engl. J. Med. 1990, 322, 898-903. [CrossRef]

17. Robertson, R.P.; Lanz, K.J.; Sutherland, D.E.; Seaquist, E.R. Relationship between diabetes and obesity 9 to 18 years after hemipancreatectomy and transplantation in donors and recipients. Transplantation 2002, 73, 736-741. [CrossRef] [PubMed] 
18. Clark, A.; Wells, C.A.; Buley, I.D.; Cruickshank, J.K.; Vanhegan, R.I.; Matthews, D.R.; Cooper, G.J.; Holman, R.R.; Turner, R.C. Islet amyloid, increased A-cells, reduced B-cells and exocrine fibrosis: Quantitative changes in the pancreas in type 2 diabetes. Diabetes Res. 1988, 9, 151-159.

19. Sakuraba, H.; Mizukami, H.; Yagihashi, N.; Wada, R.; Hanyu, C.; Yagihashi, S. Reduced beta-cell mass and expression of oxidative stress-related DNA damage in the islet of Japanese Type II diabetic patients. Diabetologia 2002, 45, 85-96. [CrossRef]

20. Ueberberg, S.; Nauck, M.A.; Uhl, W.; Montemurro, C.; Tannapfel, A.; Clark, A.; Meier, J.J. Islet Amyloid in Patients With Diabetes Due to Exocrine Pancreatic Disorders, Type 2 Diabetes, and Nondiabetic Patients. J. Clin. Endocrinol. Metab. 2020, 105, 2595-2605. [CrossRef] [PubMed]

21. Weir, G.C.; Gaglia, J.; Bonner-Weir, S. Inadequate beta-cell mass is essential for the pathogenesis of type 2 diabetes. Lancet. Diabetes Endocrinol. 2020, 8, 249-256. [CrossRef]

22. Costes, S.; Langen, R.; Gurlo, T.; Matveyenko, A.V.; Butler, P.C. beta-Cell failure in type 2 diabetes: A case of asking too much of too few? Diabetes 2013, 62, 327-335. [CrossRef]

23. Aguayo-Mazzucato, C.; Midha, A. beta-cell senescence in type 2 diabetes. Aging 2019, 11, 9967-9968. [CrossRef] [PubMed]

24. Bensellam, M.; Jonas, J.C.; Laybutt, D.R. Mechanisms of beta-cell dedifferentiation in diabetes: Recent findings and future research directions. J. Endocrinol. 2018, 236, R109-R143. [CrossRef]

25. Bruni, A.; Bornstein, S.; Linkermann, A.; Shapiro, A.M.J. Regulated Cell Death Seen through the Lens of Islet Transplantation. Cell Transpl. 2018, 27, 890-901. [CrossRef] [PubMed]

26. Hanley, S.C.; Austin, E.; Assouline-Thomas, B.; Kapeluto, J.; Blaichman, J.; Moosavi, M.; Petropavlovskaia, M.; Rosenberg, L. \{beta\}-Cell mass dynamics and islet cell plasticity in human type 2 diabetes. Endocrinology 2010, 151, 1462-1472. [CrossRef]

27. Marchetti, P.; Bugliani, M.; Lupi, R.; Marselli, L.; Masini, M.; Boggi, U.; Filipponi, F.; Weir, G.C.; Eizirik, D.L.; Cnop, M. The endoplasmic reticulum in pancreatic beta cells of type 2 diabetes patients. Diabetologia 2007, 50, 2486-2494. [CrossRef] [PubMed]

28. Marchetti, P.; Del Guerra, S.; Marselli, L.; Lupi, R.; Masini, M.; Pollera, M.; Bugliani, M.; Boggi, U.; Vistoli, F.; Mosca, F.; et al. Pancreatic islets from type 2 diabetic patients have functional defects and increased apoptosis that are ameliorated by metformin. J. Clin. Endocrinol. Metab. 2004, 89, 5535-5541. [CrossRef]

29. Masini, M.; Martino, L.; Marselli, L.; Bugliani, M.; Boggi, U.; Filipponi, F.; Marchetti, P.; De Tata, V. Ultrastructural alterations of pancreatic beta cells in human diabetes mellitus. Diabetes Metab. Res. Rev. 2017, 33, e2894. [CrossRef]

30. Jurgens, C.A.; Toukatly, M.N.; Fligner, C.L.; Udayasankar, J.; Subramanian, S.L.; Zraika, S.; Aston-Mourney, K.; Carr, D.B.; Westermark, P.; Westermark, G.T.; et al. Beta-cell loss and beta-cell apoptosis in human type 2 diabetes are related to islet amyloid deposition. Am. J. Pathol. 2011, 178, 2632-2640. [CrossRef]

31. Meier, D.T.; Entrup, L.; Templin, A.T.; Hogan, M.F.; Mellati, M.; Zraika, S.; Hull, R.L.; Kahn, S.E. The S20G substitution in hIAPP is more amyloidogenic and cytotoxic than wild-type hIAPP in mouse islets. Diabetologia 2016, 59, 2166-2171. [CrossRef] [PubMed]

32. Sakagashira, S.; Sanke, T.; Hanabusa, T.; Shimomura, H.; Ohagi, S.; Kumagaye, K.Y.; Nakajima, K.; Nanjo, K. Missense mutation of amylin gene (S20G) in Japanese NIDDM patients. Diabetes 1996, 45, 1279-1281. [CrossRef] [PubMed]

33. Haataja, L.; Gurlo, T.; Huang, C.J.; Butler, P.C. Islet amyloid in type 2 diabetes, and the toxic oligomer hypothesis. Endocr. Rev. 2008, 29, 303-316. [CrossRef] [PubMed]

34. Matveyenko, A.V.; Butler, P.C. Islet amyloid polypeptide (IAPP) transgenic rodents as models for type 2 diabetes. Ilar J. 2006, 47, 225-233. [CrossRef] [PubMed]

35. Huang, C.J.; Lin, C.Y.; Haataja, L.; Gurlo, T.; Butler, A.E.; Rizza, R.A.; Butler, P.C. High expression rates of human islet amyloid polypeptide induce endoplasmic reticulum stress mediated beta-cell apoptosis, a characteristic of humans with type 2 but not type 1 diabetes. Diabetes 2007, 56, 2016-2027. [CrossRef]

36. Laybutt, D.R.; Preston, A.M.; Akerfeldt, M.C.; Kench, J.G.; Busch, A.K.; Biankin, A.V.; Biden, T.J. Endoplasmic reticulum stress contributes to beta cell apoptosis in type 2 diabetes. Diabetologia 2007, 50, 752-763. [CrossRef] [PubMed]

37. Mizukami, H.; Takahashi, K.; Inaba, W.; Tsuboi, K.; Osonoi, S.; Yoshida, T.; Yagihashi, S. Involvement of oxidative stress-induced DNA damage, endoplasmic reticulum stress, and autophagy deficits in the decline of beta-cell mass in Japanese type 2 diabetic patients. Diabetes Care 2014, 37, 1966-1974. [CrossRef]

38. Gurlo, T.; Ryazantsev, S.; Huang, C.J.; Yeh, M.W.; Reber, H.A.; Hines, O.J.; O’Brien, T.D.; Glabe, C.G.; Butler, P.C. Evidence for proteotoxicity in beta cells in type 2 diabetes: Toxic islet amyloid polypeptide oligomers form intracellularly in the secretory pathway. Am. J. Pathol. 2010, 176, 861-869. [CrossRef] [PubMed]

39. Hull, R.L.; Zraika, S.; Udayasankar, J.; Aston-Mourney, K.; Subramanian, S.L.; Kahn, S.E. Amyloid formation in human IAPP transgenic mouse islets and pancreas, and human pancreas, is not associated with endoplasmic reticulum stress. Diabetologia 2009, 52, 1102-1111. [CrossRef]

40. Casas, S.; Gomis, R.; Gribble, F.M.; Altirriba, J.; Knuutila, S.; Novials, A. Impairment of the ubiquitin-proteasome pathway is a downstream endoplasmic reticulum stress response induced by extracellular human islet amyloid polypeptide and contributes to pancreatic beta-cell apoptosis. Diabetes 2007, 56, 2284-2294. [CrossRef]

41. Huang, C.J.; Haataja, L.; Gurlo, T.; Butler, A.E.; Wu, X.; Soeller, W.C.; Butler, P.C. Induction of endoplasmic reticulum stressinduced beta-cell apoptosis and accumulation of polyubiquitinated proteins by human islet amyloid polypeptide. Am. J. Physiol. Endocrinol. Metab. 2007, 293, E1656-E1662. [CrossRef] 
42. Matveyenko, A.V.; Gurlo, T.; Daval, M.; Butler, A.E.; Butler, P.C. Successful versus failed adaptation to high-fat diet-induced insulin resistance: The role of IAPP-induced beta-cell endoplasmic reticulum stress. Diabetes 2009, 58, 906-916. [CrossRef] [PubMed]

43. Gurlo, T.; Rivera, J.F.; Butler, A.E.; Cory, M.; Hoang, J.; Costes, S.; Butler, P.C. CHOP Contributes to, But Is Not the Only Mediator of, IAPP Induced beta-Cell Apoptosis. Mol. Endocrinol. 2016, 30, 446-454. [CrossRef]

44. Casas, S.; Novials, A.; Reimann, F.; Gomis, R.; Gribble, F.M. Calcium elevation in mouse pancreatic beta cells evoked by extracellular human islet amyloid polypeptide involves activation of the mechanosensitive ion channel TRPV4. Diabetologia 2008, 51, 2252-2262. [CrossRef] [PubMed]

45. Huang, C.J.; Gurlo, T.; Haataja, L.; Costes, S.; Daval, M.; Ryazantsev, S.; Wu, X.; Butler, A.E.; Butler, P.C. Calcium-activated calpain-2 is a mediator of beta cell dysfunction and apoptosis in type 2 diabetes. J. Biol. Chem. 2010, 285, 339-348. [CrossRef]

46. Gurlo, T.; Costes, S.; Hoang, J.D.; Rivera, J.F.; Butler, A.E.; Butler, P.C. beta Cell-specific increased expression of calpastatin prevents diabetes induced by islet amyloid polypeptide toxicity. JCI Insight 2016, 1. [CrossRef] [PubMed]

47. Costes, S.; Huang, C.J.; Gurlo, T.; Daval, M.; Matveyenko, A.V.; Rizza, R.A.; Butler, A.E.; Butler, P.C. beta-cell dysfunctional ERAD/ubiquitin/proteasome system in type 2 diabetes mediated by islet amyloid polypeptide-induced UCH-L1 deficiency. Diabetes 2011, 60, 227-238. [CrossRef]

48. Costes, S.; Gurlo, T.; Rivera, J.F.; Butler, P.C. UCHL1 deficiency exacerbates human islet amyloid polypeptide toxicity in beta-cells: Evidence of interplay between the ubiquitin/proteasome system and autophagy. Autophagy 2014, 10, 1004-1014. [CrossRef]

49. Rivera, J.F.; Gurlo, T.; Daval, M.; Huang, C.J.; Matveyenko, A.V.; Butler, P.C.; Costes, S. Human-IAPP disrupts the autophagy/lysosomal pathway in pancreatic beta-cells: Protective role of p62-positive cytoplasmic inclusions. Cell Death Differ. 2011, 18, 415-426. [CrossRef]

50. Hernandez, M.G.; Aguilar, A.G.; Burillo, J.; Oca, R.G.; Manca, M.A.; Novials, A.; Alcarraz-Vizan, G.; Guillen, C.; Benito, M. Pancreatic beta cells overexpressing hIAPP impaired mitophagy and unbalanced mitochondrial dynamics. Cell Death Dis. 2018, 9, 481. [CrossRef]

51. Kim, J.; Cheon, H.; Jeong, Y.T.; Quan, W.; Kim, K.H.; Cho, J.M.; Lim, Y.M.; Oh, S.H.; Jin, S.M.; Kim, J.H.; et al. Amyloidogenic peptide oligomer accumulation in autophagy-deficient beta cells induces diabetes. J. Clin. Investig. 2014, 124, 3311-3324. [CrossRef]

52. Kim, J.; Park, K.; Kim, M.J.; Lim, H.; Kim, K.H.; Kim, S.W.; Lee, E.S.; Kim, H.H.; Kim, S.J.; Hur, K.Y.; et al. An autophagy enhancer ameliorates diabetes of human IAPP-transgenic mice through clearance of amyloidogenic oligomer. Nat. Commun. 2021, 12, 183. [CrossRef]

53. Rivera, J.F.; Costes, S.; Gurlo, T.; Glabe, C.G.; Butler, P.C. Autophagy defends pancreatic beta cells from human islet amyloid polypeptide-induced toxicity. J. Clin. Investig. 2014, 124, 3489-3500. [CrossRef]

54. Shigihara, N.; Fukunaka, A.; Hara, A.; Komiya, K.; Honda, A.; Uchida, T.; Abe, H.; Toyofuku, Y.; Tamaki, M.; Ogihara, T.; et al. Human IAPP-induced pancreatic beta cell toxicity and its regulation by autophagy. J. Clin. Investig. 2014, 124, 3634-3644. [CrossRef] [PubMed]

55. Masini, M.; Bugliani, M.; Lupi, R.; del Guerra, S.; Boggi, U.; Filipponi, F.; Marselli, L.; Masiello, P.; Marchetti, P. Autophagy in human type 2 diabetes pancreatic beta cells. Diabetologia 2009, 52, 1083-1086. [CrossRef]

56. Zummo, F.P.; Cullen, K.S.; Honkanen-Scott, M.; Shaw, J.A.M.; Lovat, P.E.; Arden, C. Glucagon-Like Peptide 1 Protects Pancreatic beta-Cells From Death by Increasing Autophagic Flux and Restoring Lysosomal Function. Diabetes 2017, 66, 1272-1285. [CrossRef] [PubMed]

57. Singh, S.; Bhowmick, D.C.; Pany, S.; Joe, M.; Zaghlula, N.; Jeremic, A.M. Apoptosis signal regulating kinase-1 and NADPH oxidase mediate human amylin evoked redox stress and apoptosis in pancreatic beta-cells. Biochim. Biophys. Acta Biomembr. 2018, 1860, 1721-1733. [CrossRef]

58. Subramanian, S.L.; Hull, R.L.; Zraika, S.; Aston-Mourney, K.; Udayasankar, J.; Kahn, S.E. cJUN N-terminal kinase (JNK) activation mediates islet amyloid-induced beta cell apoptosis in cultured human islet amyloid polypeptide transgenic mouse islets. Diabetologia 2012, 55, 166-174. [CrossRef]

59. Zraika, S.; Hull, R.L.; Udayasankar, J.; Aston-Mourney, K.; Subramanian, S.L.; Kisilevsky, R.; Szarek, W.A.; Kahn, S.E. Oxidative stress is induced by islet amyloid formation and time-dependently mediates amyloid-induced beta cell apoptosis. Diabetologia 2009, 52, 626-635. [CrossRef]

60. Konarkowska, B.; Aitken, J.F.; Kistler, J.; Zhang, S.; Cooper, G.J. Thiol reducing compounds prevent human amylin-evoked cytotoxicity. Febs. J. 2005, 272, 4949-4959. [CrossRef]

61. Donath, M.Y.; Boni-Schnetzler, M.; Ellingsgaard, H.; Halban, P.A.; Ehses, J.A. Cytokine production by islets in health and diabetes: Cellular origin, regulation and function. Trends Endocrinol. Metab. 2010, 21, 261-267. [CrossRef] [PubMed]

62. Kulak, K.; Westermark, G.T.; Papac-Milicevic, N.; Renstrom, E.; Blom, A.M.; King, B.C. The human serum protein C4b-binding protein inhibits pancreatic IAPP-induced inflammasome activation. Diabetologia 2017, 60, 1522-1533. [CrossRef] [PubMed]

63. Meier, D.T.; Morcos, M.; Samarasekera, T.; Zraika, S.; Hull, R.L.; Kahn, S.E. Islet amyloid formation is an important determinant for inducing islet inflammation in high-fat-fed human IAPP transgenic mice. Diabetologia 2014, 57, 1884-1888. [CrossRef] [PubMed]

64. Masters, S.L.; Dunne, A.; Subramanian, S.L.; Hull, R.L.; Tannahill, G.M.; Sharp, F.A.; Becker, C.; Franchi, L.; Yoshihara, E.; Chen, Z.; et al. Activation of the NLRP3 inflammasome by islet amyloid polypeptide provides a mechanism for enhanced IL-1beta in type 2 diabetes. Nat. Immunol. 2010, 11, 897-904. [CrossRef] [PubMed] 
65. Westwell-Roper, C.Y.; Chehroudi, C.A.; Denroche, H.C.; Courtade, J.A.; Ehses, J.A.; Verchere, C.B. IL-1 mediates amyloidassociated islet dysfunction and inflammation in human islet amyloid polypeptide transgenic mice. Diabetologia 2015, 58, 575-585. [CrossRef]

66. Westwell-Roper, C.Y.; Ehses, J.A.; Verchere, C.B. Resident macrophages mediate islet amyloid polypeptide-induced islet IL-1beta production and beta-cell dysfunction. Diabetes 2014, 63, 1698-1711. [CrossRef]

67. Park, Y.J.; Lee, S.; Kieffer, T.J.; Warnock, G.L.; Safikhan, N.; Speck, M.; Hao, Z.; Woo, M.; Marzban, L. Deletion of Fas protects islet beta cells from cytotoxic effects of human islet amyloid polypeptide. Diabetologia 2012, 55, 1035-1047. [CrossRef]

68. Park, Y.J.; Warnock, G.L.; Ao, Z.; Safikhan, N.; Meloche, M.; Asadi, A.; Kieffer, T.J.; Marzban, L. Dual role of interleukin-1beta in islet amyloid formation and its beta-cell toxicity: Implications for type 2 diabetes and islet transplantation. Diabetes Obes. Metab. 2017, 19, 682-694. [CrossRef]

69. Park, Y.J.; Woo, M.; Kieffer, T.J.; Hakem, R.; Safikhan, N.; Yang, F.; Ao, Z.; Warnock, G.L.; Marzban, L. The role of caspase-8 in amyloid-induced beta cell death in human and mouse islets. Diabetologia 2014, 57, 765-775. [CrossRef]

70. Hui, Q.; Asadi, A.; Park, Y.J.; Kieffer, T.J.; Ao, Z.; Warnock, G.L.; Marzban, L. Amyloid formation disrupts the balance between interleukin-1beta and interleukin-1 receptor antagonist in human islets. Mol. Metab. 2017, 6, 833-844. [CrossRef]

71. Abedini, A.; Cao, P.; Plesner, A.; Zhang, J.; He, M.; Derk, J.; Patil, S.A.; Rosario, R.; Lonier, J.; Song, F.; et al. RAGE binds preamyloid IAPP intermediates and mediates pancreatic beta cell proteotoxicity. J. Clin. Investig. 2018, 128, 682-698. [CrossRef] [PubMed]

72. Lytrivi, M.; Castell, A.L.; Poitout, V.; Cnop, M. Recent Insights Into Mechanisms of beta-Cell Lipo- and Glucolipotoxicity in Type 2 Diabetes. J. Mol. Biol. 2020, 432, 1514-1534. [CrossRef]

73. Prentki, M.; Peyot, M.L.; Masiello, P.; Madiraju, S.R.M. Nutrient-Induced Metabolic Stress, Adaptation, Detoxification, and Toxicity in the Pancreatic beta-Cell. Diabetes 2020, 69, 279-290. [CrossRef] [PubMed]

74. Weir, G.C. Glucolipotoxicity, beta-Cells, and Diabetes: The Emperor Has No Clothes. Diabetes 2020, 69, 273-278. [CrossRef]

75. Forouhi, N.G.; Koulman, A.; Sharp, S.J.; Imamura, F.; Kroger, J.; Schulze, M.B.; Crowe, F.L.; Huerta, J.M.; Guevara, M.; Beulens, J.W.; et al. Differences in the prospective association between individual plasma phospholipid saturated fatty acids and incident type 2 diabetes: The EPIC-InterAct case-cohort study. Lancet Diabetes Endocrinol. 2014, 2, 810-818. [CrossRef]

76. El-Assaad, W.; Buteau, J.; Peyot, M.L.; Nolan, C.; Roduit, R.; Hardy, S.; Joly, E.; Dbaibo, G.; Rosenberg, L.; Prentki, M. Saturated fatty acids synergize with elevated glucose to cause pancreatic beta-cell death. Endocrinology 2003, 144, 4154-4163. [CrossRef]

77. Sargsyan, E.; Artemenko, K.; Manukyan, L.; Bergquist, J.; Bergsten, P. Oleate protects beta-cells from the toxic effect of palmitate by activating pro-survival pathways of the ER stress response. Biochim. Biophys. Acta 2016, 1861, 1151-1160. [CrossRef] [PubMed]

78. Cnop, M.; Abdulkarim, B.; Bottu, G.; Cunha, D.A.; Igoillo-Esteve, M.; Masini, M.; Turatsinze, J.V.; Griebel, T.; Villate, O.; Santin, I.; et al. RNA sequencing identifies dysregulation of the human pancreatic islet transcriptome by the saturated fatty acid palmitate. Diabetes 2014, 63, 1978-1993. [CrossRef]

79. Cunha, D.A.; Hekerman, P.; Ladriere, L.; Bazarra-Castro, A.; Ortis, F.; Wakeham, M.C.; Moore, F.; Rasschaert, J.; Cardozo, A.K.; Bellomo, E.; et al. Initiation and execution of lipotoxic ER stress in pancreatic beta-cells. J. Cell Sci. 2008, 121, 2308-2318. [CrossRef]

80. Gilon, P.; Chae, H.Y.; Rutter, G.A.; Ravier, M.A. Calcium signaling in pancreatic beta-cells in health and in Type 2 diabetes. Cell Calcium. 2014, 56, 340-361. [CrossRef]

81. Gwiazda, K.S.; Yang, T.L.; Lin, Y.; Johnson, J.D. Effects of palmitate on ER and cytosolic Ca2+ homeostasis in beta-cells. Am. J. Physiol. Endocrinol. Metab. 2009, 296, E690-E701. [CrossRef]

82. Hara, T.; Mahadevan, J.; Kanekura, K.; Hara, M.; Lu, S.; Urano, F. Calcium efflux from the endoplasmic reticulum leads to beta-cell death. Endocrinology 2014, 155, 758-768. [CrossRef] [PubMed]

83. Boslem, E.; Weir, J.M.; MacIntosh, G.; Sue, N.; Cantley, J.; Meikle, P.J.; Biden, T.J. Alteration of endoplasmic reticulum lipid rafts contributes to lipotoxicity in pancreatic beta-cells. J. Biol. Chem. 2013, 288, 26569-26582. [CrossRef]

84. Baldwin, A.C.; Green, C.D.; Olson, L.K.; Moxley, M.A.; Corbett, J.A. A role for aberrant protein palmitoylation in FFA-induced ER stress and beta-cell death. Am. J. Physiol. Endocrinol. Metab. 2012, 302, E1390-E1398. [CrossRef]

85. Preston, A.M.; Gurisik, E.; Bartley, C.; Laybutt, D.R.; Biden, T.J. Reduced endoplasmic reticulum (ER)-to-Golgi protein trafficking contributes to ER stress in lipotoxic mouse beta cells by promoting protein overload. Diabetologia 2009, 52, 2369-2373. [CrossRef] [PubMed]

86. Lytrivi, M.; Ghaddar, K.; Lopes, M.; Rosengren, V.; Piron, A.; Yi, X.; Johansson, H.; Lehtio, J.; Igoillo-Esteve, M.; Cunha, D.A.; et al. Combined transcriptome and proteome profiling of the pancreatic beta-cell response to palmitate unveils key pathways of beta-cell lipotoxicity. BMC Genom. 2020, 21, 590. [CrossRef]

87. Cunha, D.A.; Igoillo-Esteve, M.; Gurzov, E.N.; Germano, C.M.; Naamane, N.; Marhfour, I.; Fukaya, M.; Vanderwinden, J.M.; Gysemans, C.; Mathieu, C.; et al. Death protein 5 and p53-upregulated modulator of apoptosis mediate the endoplasmic reticulum stress-mitochondrial dialog triggering lipotoxic rodent and human beta-cell apoptosis. Diabetes 2012, 61, 2763-2775. [CrossRef] [PubMed]

88. Litwak, S.A.; Wali, J.A.; Pappas, E.G.; Saadi, H.; Stanley, W.J.; Varanasi, L.C.; Kay, T.W.; Thomas, H.E.; Gurzov, E.N. Lipotoxic Stress Induces Pancreatic beta-Cell Apoptosis through Modulation of Bcl-2 Proteins by the Ubiquitin-Proteasome System. J. Diabetes Res. 2015, 2015, 280615. [CrossRef] [PubMed]

89. Georgiadou, E.; Rutter, G.A. Control by $\mathrm{Ca}(2+)$ of mitochondrial structure and function in pancreatic beta-cells. Cell Calcium. 2020, 91, 102282. [CrossRef] 
90. Molina, A.J.; Wikstrom, J.D.; Stiles, L.; Las, G.; Mohamed, H.; Elorza, A.; Walzer, G.; Twig, G.; Katz, S.; Corkey, B.E.; et al. Mitochondrial networking protects beta-cells from nutrient-induced apoptosis. Diabetes 2009, 58, 2303-2315. [CrossRef]

91. Grishko, V.; Rachek, L.; Musiyenko, S.; Ledoux, S.P.; Wilson, G.L. Involvement of mtDNA damage in free fatty acid-induced apoptosis. Free Radic Biol. Med. 2005, 38, 755-762. [CrossRef] [PubMed]

92. Eguchi, N.; Vaziri, N.D.; Dafoe, D.C.; Ichii, H. The Role of Oxidative Stress in Pancreatic beta Cell Dysfunction in Diabetes. Int. J. Mol. Sci. 2021, 22, 1509. [CrossRef]

93. Elsner, M.; Gehrmann, W.; Lenzen, S. Peroxisome-generated hydrogen peroxide as important mediator of lipotoxicity in insulin-producing cells. Diabetes 2011, 60, 200-208. [CrossRef] [PubMed]

94. Morgan, D.; Oliveira-Emilio, H.R.; Keane, D.; Hirata, A.E.; Santos da Rocha, M.; Bordin, S.; Curi, R.; Newsholme, P.; Carpinelli, A.R. Glucose, palmitate and pro-inflammatory cytokines modulate production and activity of a phagocyte-like NADPH oxidase in rat pancreatic islets and a clonal beta cell line. Diabetologia 2007, 50, 359-369. [CrossRef] [PubMed]

95. Komiya, K.; Uchida, T.; Ueno, T.; Koike, M.; Abe, H.; Hirose, T.; Kawamori, R.; Uchiyama, Y.; Kominami, E.; Fujitani, Y.; et al. Free fatty acids stimulate autophagy in pancreatic beta-cells via JNK pathway. Biochem. Biophys. Res. Commun. 2010, 401, 561-567. [CrossRef]

96. Las, G.; Serada, S.B.; Wikstrom, J.D.; Twig, G.; Shirihai, O.S. Fatty acids suppress autophagic turnover in beta-cells. J. Biol. Chem. 2011, 286, 42534-42544. [CrossRef]

97. Mir, S.U.; George, N.M.; Zahoor, L.; Harms, R.; Guinn, Z.; Sarvetnick, N.E. Inhibition of autophagic turnover in beta-cells by fatty acids and glucose leads to apoptotic cell death. J. Biol. Chem. 2015, 290, 6071-6085. [CrossRef]

98. Trudeau, K.M.; Colby, A.H.; Zeng, J.; Las, G.; Feng, J.H.; Grinstaff, M.W.; Shirihai, O.S. Lysosome acidification by photoactivated nanoparticles restores autophagy under lipotoxicity. J. Cell Biol. 2016, 214, 25-34. [CrossRef]

99. Chen, Y.Y.; Sun, L.Q.; Wang, B.A.; Zou, X.M.; Mu, Y.M.; Lu, J.M. Palmitate induces autophagy in pancreatic beta-cells via endoplasmic reticulum stress and its downstream JNK pathway. Int. J. Mol. Med. 2013, 32, 1401-1406. [CrossRef]

100. Ebato, C.; Uchida, T.; Arakawa, M.; Komatsu, M.; Ueno, T.; Komiya, K.; Azuma, K.; Hirose, T.; Tanaka, K.; Kominami, E.; et al. Autophagy is important in islet homeostasis and compensatory increase of beta cell mass in response to high-fat diet. Cell Metab. 2008, 8, 325-332. [CrossRef]

101. Martino, L.; Masini, M.; Novelli, M.; Beffy, P.; Bugliani, M.; Marselli, L.; Masiello, P.; Marchetti, P.; De Tata, V. Palmitate activates autophagy in INS-1E beta-cells and in isolated rat and human pancreatic islets. PLoS ONE 2012, 7, e36188. [CrossRef]

102. Bugliani, M.; Mossuto, S.; Grano, F.; Suleiman, M.; Marselli, L.; Boggi, U.; De Simone, P.; Eizirik, D.L.; Cnop, M.; Marchetti, P.; et al. Modulation of Autophagy Influences the Function and Survival of Human Pancreatic Beta Cells Under Endoplasmic Reticulum Stress Conditions and in Type 2 Diabetes. Front. Endocrinol. 2019, 10, 52. [CrossRef] [PubMed]

103. Hong, S.W.; Lee, J.; Kim, M.J.; Moon, S.J.; Kwon, H.; Park, S.E.; Rhee, E.J.; Lee, W.Y. Clusterin Protects Lipotoxicity-Induced Apoptosis via Upregulation of Autophagy in Insulin-Secreting Cells. Endocrinol. Metab. 2020, 35, 943-953. [CrossRef] [PubMed]

104. Boni-Schnetzler, M.; Boller, S.; Debray, S.; Bouzakri, K.; Meier, D.T.; Prazak, R.; Kerr-Conte, J.; Pattou, F.; Ehses, J.A.; Schuit, F.C.; et al. Free fatty acids induce a proinflammatory response in islets via the abundantly expressed interleukin-1 receptor I. Endocrinology 2009, 150, 5218-5229. [CrossRef] [PubMed]

105. Igoillo-Esteve, M.; Marselli, L.; Cunha, D.A.; Ladriere, L.; Ortis, F.; Grieco, F.A.; Dotta, F.; Weir, G.C.; Marchetti, P.; Eizirik, D.L.; et al. Palmitate induces a pro-inflammatory response in human pancreatic islets that mimics CCL2 expression by beta cells in type 2 diabetes. Diabetologia 2010, 53, 1395-1405. [CrossRef] [PubMed]

106. Wali, J.A.; Gurzov, E.N.; Fynch, S.; Elkerbout, L.; Kay, T.W.; Masters, S.L.; Thomas, H.E. Activation of the NLRP3 inflammasome complex is not required for stress-induced death of pancreatic islets. PLoS ONE 2014, 9, e113128. [CrossRef] [PubMed]

107. Hu, H.Q.; Qiao, J.T.; Liu, F.Q.; Wang, J.B.; Sha, S.; He, Q.; Cui, C.; Song, J.; Zang, N.; Wang, L.S.; et al. The STING-IRF3 pathway is involved in lipotoxic injury of pancreatic beta cells in type 2 diabetes. Mol. Cell Endocrinol. 2020, 518, 110890. [CrossRef]

108. Inoue, H.; Shirakawa, J.; Togashi, Y.; Tajima, K.; Okuyama, T.; Kyohara, M.; Tanaka, Y.; Orime, K.; Saisho, Y.; Yamada, T.; et al. Signaling between pancreatic beta cells and macrophages via S100 calcium-binding protein A8 exacerbates beta-cell apoptosis and islet inflammation. J. Biol. Chem. 2018, 293, 5934-5946. [CrossRef] [PubMed]

109. Bensellam, M.; Laybutt, D.R.; Jonas, J.C. The molecular mechanisms of pancreatic beta-cell glucotoxicity: Recent findings and future research directions. Mol. Cell Endocrinol. 2012, 364, 1-27. [CrossRef]

110. Brun, T.; Li, N.; Jourdain, A.A.; Gaudet, P.; Duhamel, D.; Meyer, J.; Bosco, D.; Maechler, P. Diabetogenic milieus induce specific changes in mitochondrial transcriptome and differentiation of human pancreatic islets. Hum. Mol. Genet. 2015, 24, 5270-5284. [CrossRef]

111. Federici, M.; Hribal, M.; Perego, L.; Ranalli, M.; Caradonna, Z.; Perego, C.; Usellini, L.; Nano, R.; Bonini, P.; Bertuzzi, F.; et al. High glucose causes apoptosis in cultured human pancreatic islets of Langerhans: A potential role for regulation of specific Bcl family genes toward an apoptotic cell death program. Diabetes 2001, 50, 1290-1301. [CrossRef] [PubMed]

112. Maedler, K.; Schulthess, F.T.; Bielman, C.; Berney, T.; Bonny, C.; Prentki, M.; Donath, M.Y.; Roduit, R. Glucose and leptin induce apoptosis in human beta-cells and impair glucose-stimulated insulin secretion through activation of c-Jun N-terminal kinases. FASEB J. 2008, 22, 1905-1913. [CrossRef] [PubMed]

113. Hall, E.; Jonsson, J.; Ofori, J.K.; Volkov, P.; Perfilyev, A.; Dekker Nitert, M.; Eliasson, L.; Ling, C.; Bacos, K. Glucolipotoxicity Alters Insulin Secretion via Epigenetic Changes in Human Islets. Diabetes 2019, 68, 1965-1974. [CrossRef] [PubMed]

114. Kim, J.W.; Yoon, K.H. Glucolipotoxicity in Pancreatic beta-Cells. Diabetes Metab. J. 2011, 35, 444-450. [CrossRef] 
115. Poitout, V.; Amyot, J.; Semache, M.; Zarrouki, B.; Hagman, D.; Fontes, G. Glucolipotoxicity of the pancreatic beta cell. Biochim. Biophys. Acta 2010, 1801, 289-298. [CrossRef]

116. Poitout, V.; Robertson, R.P. Glucolipotoxicity: Fuel excess and beta-cell dysfunction. Endocr. Rev. 2008, 29, 351-366. [CrossRef]

117. Vogel, J.; Yin, J.; Su, L.; Wang, S.X.; Zessis, R.; Fowler, S.; Chiu, C.H.; Wilson, A.C.; Chen, A.; Zecri, F.; et al. A Phenotypic Screen Identifies Calcium Overload as a Key Mechanism of beta-Cell Glucolipotoxicity. Diabetes 2020, 69, 1032-1041. [CrossRef]

118. Wali, J.A.; Rondas, D.; McKenzie, M.D.; Zhao, Y.; Elkerbout, L.; Fynch, S.; Gurzov, E.N.; Akira, S.; Mathieu, C.; Kay, T.W.; et al. The proapoptotic BH3-only proteins Bim and Puma are downstream of endoplasmic reticulum and mitochondrial oxidative stress in pancreatic islets in response to glucotoxicity. Cell Death Dis. 2014, 5, e1124. [CrossRef] [PubMed]

119. Bachar, E.; Ariav, Y.; Ketzinel-Gilad, M.; Cerasi, E.; Kaiser, N.; Leibowitz, G. Glucose amplifies fatty acid-induced endoplasmic reticulum stress in pancreatic beta-cells via activation of mTORC1. PLoS ONE 2009, 4, e4954. [CrossRef]

120. Tanaka, Y.; Tran, P.O.; Harmon, J.; Robertson, R.P. A role for glutathione peroxidase in protecting pancreatic beta cells against oxidative stress in a model of glucose toxicity. Proc. Natl. Acad. Sci. USA 2002, 99, 12363-12368. [CrossRef] [PubMed]

121. Hansen, J.B.; Dos Santos, L.R.B.; Liu, Y.; Prentice, K.J.; Teudt, F.; Tonnesen, M.; Jonas, J.C.; Wheeler, M.B.; Mandrup-Poulsen, T. Glucolipotoxic conditions induce beta-cell iron import, cytosolic ROS formation and apoptosis. J. Mol. Endocrinol. 2018, 61, 69-77. [CrossRef] [PubMed]

122. Men, X.; Wang, H.; Li, M.; Cai, H.; Xu, S.; Zhang, W.; Xu, Y.; Ye, L.; Yang, W.; Wollheim, C.B.; et al. Dynamin-related protein 1 mediates high glucose induced pancreatic beta cell apoptosis. Int. J. Biochem. Cell Biol. 2009, 41, 879-890. [CrossRef] [PubMed]

123. Broca, C.; Varin, E.; Armanet, M.; Tourrel-Cuzin, C.; Bosco, D.; Dalle, S.; Wojtusciszyn, A. Proteasome dysfunction mediates high glucose-induced apoptosis in rodent beta cells and human islets. PLoS ONE 2014, 9, e92066. [CrossRef]

124. Kaniuk, N.A.; Kiraly, M.; Bates, H.; Vranic, M.; Volchuk, A.; Brumell, J.H. Ubiquitinated-protein aggregates form in pancreatic beta-cells during diabetes-induced oxidative stress and are regulated by autophagy. Diabetes 2007, 56, 930-939. [CrossRef] [PubMed]

125. Zhang, J.; Chen, K.; Wang, L.; Wan, X.; Shrestha, C.; Zhou, J.; Mo, Z. Phosphatase and tensin homologue (PTEN)-induced putative kinase 1 reduces pancreatic beta-cells apoptosis in glucotoxicity through activation of autophagy. Biochem. Biophys. Res. Commun. 2016, 476, 299-305. [CrossRef]

126. Choi, S.E.; Lee, S.M.; Lee, Y.J.; Li, L.J.; Lee, S.J.; Lee, J.H.; Kim, Y.; Jun, H.S.; Lee, K.W.; Kang, Y. Protective role of autophagy in palmitate-induced INS-1 beta-cell death. Endocrinology 2009, 150, 126-134. [CrossRef]

127. Ehses, J.A.; Boni-Schnetzler, M.; Faulenbach, M.; Donath, M.Y. Macrophages, cytokines and beta-cell death in Type 2 diabetes. Biochem. Soc. Trans. 2008, 36, 340-342. [CrossRef]

128. Maedler, K.; Sergeev, P.; Ris, F.; Oberholzer, J.; Joller-Jemelka, H.I.; Spinas, G.A.; Kaiser, N.; Halban, P.A.; Donath, M.Y. Glucoseinduced beta cell production of IL-1beta contributes to glucotoxicity in human pancreatic islets. J. Clin. Investig. 2002, 110, 851-860. [CrossRef]

129. Welsh, N.; Cnop, M.; Kharroubi, I.; Bugliani, M.; Lupi, R.; Marchetti, P.; Eizirik, D.L. Is there a role for locally produced interleukin-1 in the deleterious effects of high glucose or the type 2 diabetes milieu to human pancreatic islets? Diabetes 2005, 54, 3238-3244. [CrossRef]

130. Ghiasi, S.M.; Dahllof, M.S.; Osmai, Y.; Osmai, M.; Jakobsen, K.K.; Aivazidis, A.; Tyrberg, B.; Perruzza, L.; Prause, M.C.B.; Christensen, D.P.; et al. Regulation of the beta-cell inflammasome and contribution to stress-induced cellular dysfunction and apoptosis. Mol. Cell Endocrinol. 2018, 478, 106-114. [CrossRef]

131. McKenzie, M.D.; Jamieson, E.; Jansen, E.S.; Scott, C.L.; Huang, D.C.; Bouillet, P.; Allison, J.; Kay, T.W.; Strasser, A.; Thomas, H.E. Glucose induces pancreatic islet cell apoptosis that requires the BH3-only proteins Bim and Puma and multi-BH domain protein Bax. Diabetes 2010, 59, 644-652. [CrossRef]

132. Bagnati, M.; Ogunkolade, B.W.; Marshall, C.; Tucci, C.; Hanna, K.; Jones, T.A.; Bugliani, M.; Nedjai, B.; Caton, P.W.; Kieswich, J.; et al. Glucolipotoxicity initiates pancreatic beta-cell death through TNFR5/CD40-mediated STAT1 and NF-kappaB activation. Cell Death Dis. 2016, 7, e2329. [CrossRef] [PubMed]

133. Li, Y.; Zhang, T.; Zhou, Y.; Sun, Y.; Cao, Y.; Chang, X.; Zhu, Y.; Han, X. A Presenilin/Notch1 pathway regulated by miR-375, miR-30a, and miR-34a mediates glucotoxicity induced-pancreatic beta cell apoptosis. Sci. Rep. 2016, 6, 36136. [CrossRef]

134. Huang, Q.; You, W.; Li, Y.; Sun, Y.; Zhou, Y.; Zhang, Y.; Liu, D.; Zhan, S.; Zhu, Y.; Han, X. Glucolipotoxicity-Inhibited miR-299-5p Regulates Pancreatic beta-Cell Function and Survival. Diabetes 2018, 67, 2280-2292. [CrossRef]

135. Ruiz, L.; Gurlo, T.; Ravier, M.A.; Wojtusciszyn, A.; Mathieu, J.; Brown, M.R.; Broca, C.; Bertrand, G.; Butler, P.C.; Matveyenko, A.V.; et al. Proteasomal degradation of the histone acetyl transferase p300 contributes to beta-cell injury in a diabetes environment. Cell Death Dis. 2018, 9, 600. [CrossRef] [PubMed]

136. Costes, S.; Vandewalle, B.; Tourrel-Cuzin, C.; Broca, C.; Linck, N.; Bertrand, G.; Kerr-Conte, J.; Portha, B.; Pattou, F.; Bockaert, J.; et al. Degradation of cAMP-responsive element-binding protein by the ubiquitin-proteasome pathway contributes to glucotoxicity in beta-cells and human pancreatic islets. Diabetes 2009, 58, 1105-1115. [CrossRef] [PubMed]

137. Khadija, S.; Veluthakal, R.; Sidarala, V.; Kowluru, A. Glucotoxic and diabetic conditions induce caspase 6-mediated degradation of nuclear lamin A in human islets, rodent islets and INS-1 832/13 cells. Apoptosis 2014, 19, 1691-1701. [CrossRef]

138. Syeda, K.; Mohammed, A.M.; Arora, D.K.; Kowluru, A. Glucotoxic conditions induce endoplasmic reticulum stress to cause caspase 3 mediated lamin B degradation in pancreatic beta-cells: Protection by nifedipine. Biochem. Pharm. 2013, 86, 1338-1346. [CrossRef] 
139. Nauck, M.A.; Meier, J.J. Incretin hormones: Their role in health and disease. Diabetes Obes. Metab. 2018,20 (Suppl. S1), 5-21. [CrossRef]

140. Nauck, M.A.; Quast, D.R.; Wefers, J.; Meier, J.J. GLP-1 receptor agonists in the treatment of type 2 diabetes-state-of-the-art. Mol. Metab. 2020, 101102. [CrossRef]

141. Davies, M.J.; Bianchi, C.; Del Prato, S. Use of incretin-based medications: What do current international recommendations suggest with respect to GLP-1 receptor agonists and DPP-4 inhibitors? Metabolism 2020, 107, 154242. [CrossRef] [PubMed]

142. Oduori, O.S.; Murao, N.; Shimomura, K.; Takahashi, H.; Zhang, Q.; Dou, H.; Sakai, S.; Minami, K.; Chanclon, B.; Guida, C.; et al. Gs/Gq signaling switch in beta cells defines incretin effectiveness in diabetes. J. Clin. Investig. 2020, 130, 6639-6655. [CrossRef] [PubMed]

143. Shigeto, M.; Ramracheya, R.; Tarasov, A.I.; Cha, C.Y.; Chibalina, M.V.; Hastoy, B.; Philippaert, K.; Reinbothe, T.; Rorsman, N.; Salehi, A.; et al. GLP-1 stimulates insulin secretion by PKC-dependent TRPM4 and TRPM5 activation. J. Clin. Investig. 2015, 125, 4714-4728. [CrossRef] [PubMed]

144. Tomas, A.; Jones, B.; Leech, C. New Insights into Beta-Cell GLP-1 Receptor and cAMP Signaling. J. Mol. Biol. 2020, 432, 1347-1366. [CrossRef] [PubMed]

145. Sonoda, N.; Imamura, T.; Yoshizaki, T.; Babendure, J.L.; Lu, J.C.; Olefsky, J.M. Beta-Arrestin-1 mediates glucagon-like peptide-1 signaling to insulin secretion in cultured pancreatic beta cells. Proc. Natl. Acad. Sci. USA 2008, 105, 6614-6619. [CrossRef]

146. Jorgensen, R.; Martini, L.; Schwartz, T.W.; Elling, C.E. Characterization of glucagon-like peptide-1 receptor beta-arrestin 2 interaction: A high-affinity receptor phenotype. Mol. Endocrinol. 2005, 19, 812-823. [CrossRef]

147. Quoyer, J.; Longuet, C.; Broca, C.; Linck, N.; Costes, S.; Varin, E.; Bockaert, J.; Bertrand, G.; Dalle, S. GLP-1 mediates antiapoptotic effect by phosphorylating Bad through a beta-arrestin 1-mediated ERK1/2 activation in pancreatic beta-cells. J. Biol. Chem. 2010, 285, 1989-2002. [CrossRef] [PubMed]

148. Fletcher, M.M.; Halls, M.L.; Zhao, P.; Clydesdale, L.; Christopoulos, A.; Sexton, P.M.; Wootten, D. Glucagon-like peptide-1 receptor internalisation controls spatiotemporal signalling mediated by biased agonists. Biochem. Pharmacol. 2018, 156, 406-419. [CrossRef]

149. Talbot, J.; Joly, E.; Prentki, M.; Buteau, J. beta-Arrestin1 mediated recruitment of c-Src underlies the proliferative action of glucagon-like peptide-1 in pancreatic beta INS832/13 cells. Mol. Cell Endocrinol. 2012, 354, 65-70. [CrossRef]

150. Dalle, S.; Burcelin, R.; Gourdy, P. Specific actions of GLP-1 receptor agonists and DPP4 inhibitors for the treatment of pancreatic beta-cell impairments in type 2 diabetes. Cell Signal. 2013, 25, 570-579. [CrossRef]

151. Moffett, R.C.; Patterson, S.; Irwin, N.; Flatt, P.R. Positive effects of GLP-1 receptor activation with liraglutide on pancreatic islet morphology and metabolic control in C57BL/KsJ db/db mice with degenerative diabetes. Diabetes Metab. Res. Rev. 2015, 31, 248-255. [CrossRef] [PubMed]

152. Kimura, T.; Obata, A.; Shimoda, M.; Hirukawa, H.; Kanda-Kimura, Y.; Nogami, Y.; Kohara, K.; Nakanishi, S.; Mune, T.; Kaku, K.; et al. Durability of protective effect of dulaglutide on pancreatic beta-cells in diabetic mice: GLP-1 receptor expression is not reduced despite long-term dulaglutide exposure. Diabetes Metab. 2018, 44, 250-260. [CrossRef] [PubMed]

153. Fan, M.; Jiang, H.; Zhang, Y.; Ma, Y.; Li, L.; Wu, J. Liraglutide Enhances Autophagy and Promotes Pancreatic beta Cell Proliferation to Ameliorate Type 2 Diabetes in High-Fat-Fed and Streptozotocin-Treated Mice. Med. Sci. Monit. 2018, 24, 2310-2316. [CrossRef]

154. Tamura, K.; Minami, K.; Kudo, M.; Iemoto, K.; Takahashi, H.; Seino, S. Liraglutide improves pancreatic Beta cell mass and function in alloxan-induced diabetic mice. PLoS ONE 2015, 10, e0126003. [CrossRef] [PubMed]

155. Dai, C.; Hang, Y.; Shostak, A.; Poffenberger, G.; Hart, N.; Prasad, N.; Phillips, N.; Levy, S.E.; Greiner, D.L.; Shultz, L.D.; et al. Age-dependent human beta cell proliferation induced by glucagon-like peptide 1 and calcineurin signaling. J. Clin. Investig. 2017, 127, 3835-3844. [CrossRef]

156. Li, Y.; Hansotia, T.; Yusta, B.; Ris, F.; Halban, P.A.; Drucker, D.J. Glucagon-like peptide-1 receptor signaling modulates beta cell apoptosis. J. Biol. Chem. 2003, 278, 471-478. [CrossRef] [PubMed]

157. Farilla, L.; Bulotta, A.; Hirshberg, B.; Li Calzi, S.; Khoury, N.; Noushmehr, H.; Bertolotto, C.; Di Mario, U.; Harlan, D.M.; Perfetti, R. Glucagon-like peptide 1 inhibits cell apoptosis and improves glucose responsiveness of freshly isolated human islets. Endocrinology 2003, 144, 5149-5158. [CrossRef] [PubMed]

158. Huang, C.; Yuan, L.; Cao, S. Endogenous GLP-1 as a key self-defense molecule against lipotoxicity in pancreatic islets. Int. J. Mol. Med. 2015, 36, 173-185. [CrossRef] [PubMed]

159. Buteau, J.; El-Assaad, W.; Rhodes, C.J.; Rosenberg, L.; Joly, E.; Prentki, M. Glucagon-like peptide-1 prevents beta cell glucolipotoxicity. Diabetologia 2004, 47, 806-815. [CrossRef]

160. Park, S.H.; Park, J.H.; Shim, H.M.; Na, A.Y.; Bae, K.C.; Lim, J.G.; Song, D.K. Protection of pancreatic beta-cells against glucotoxicity by short-term treatment with GLP-1. Biochem. Biophys. Res. Commun. 2015, 459, 561-567. [CrossRef] [PubMed]

161. Kornelius, E.; Li, H.H.; Peng, C.H.; Yang, Y.S.; Chen, W.J.; Chang, Y.Z.; Bai, Y.C.; Liu, S.; Huang, C.N.; Lin, C.L. Liraglutide protects against glucolipotoxicity-induced RIN-m5F beta-cell apoptosis through restoration of PDX1 expression. J. Cell Mol. Med. 2019, 23, 619-629. [CrossRef]

162. Cunha, D.A.; Ladriere, L.; Ortis, F.; Igoillo-Esteve, M.; Gurzov, E.N.; Lupi, R.; Marchetti, P.; Eizirik, D.L.; Cnop, M. Glucagon-like peptide-1 agonists protect pancreatic beta-cells from lipotoxic endoplasmic reticulum stress through upregulation of BiP and JunB. Diabetes 2009, 58, 2851-2862. [CrossRef]

163. Ding, M.; Fang, Q.H.; Cui, Y.T.; Shen, Q.L.; Liu, Q.; Wang, P.H.; Yu, D.M.; Li, C.J. Liraglutide prevents beta-cell apoptosis via inactivation of NOX2 and its related signaling pathway. J. Diabetes Complicat. 2019, 33, 267-277. [CrossRef] [PubMed] 
164. Shen, X.; Luo, L.; Yang, M.; Lin, Y.; Li, J.; Yang, L. Exendin4 inhibits lipotoxicityinduced oxidative stress in betacells by inhibiting the activation of TLR4/NFkappaB signaling pathway. Int. J. Mol. Med. 2020, 45, 1237-1249. [CrossRef] [PubMed]

165. Jiang, D.; Wan, F. Exendin-4 protects INS-1 cells against palmitate-induced apoptosis through the IRE1alpha-Xbp1 signaling pathway. Exp. Ther. Med. 2018, 16, 1029-1035. [CrossRef]

166. Varin, E.M.; Wojtusciszyn, A.; Broca, C.; Muller, D.; Ravier, M.A.; Ceppo, F.; Renard, E.; Tanti, J.F.; Dalle, S. Inhibition of the MAP3 kinase Tpl2 protects rodent and human beta-cells from apoptosis and dysfunction induced by cytokines and enhances anti-inflammatory actions of exendin-4. Cell Death Dis. 2016, 7, e2065. [CrossRef]

167. Son, D.O.; Liu, W.; Li, X.; Prud'homme, G.J.; Wang, Q. Combined effect of GABA and glucagon-like peptide-1 receptor agonist on cytokine-induced apoptosis in pancreatic beta-cell line and isolated human islets. J. Diabetes 2019, 11, 563-572. [CrossRef]

168. Ferdaoussi, M.; Abdelli, S.; Yang, J.Y.; Cornu, M.; Niederhauser, G.; Favre, D.; Widmann, C.; Regazzi, R.; Thorens, B.; Waeber, G.; et al. Exendin-4 protects beta-cells from interleukin-1 beta-induced apoptosis by interfering with the c-Jun NH2-terminal kinase pathway. Diabetes 2008, 57, 1205-1215. [CrossRef] [PubMed]

169. Rondas, D.; Bugliani, M.; D’Hertog, W.; Lage, K.; Masini, M.; Waelkens, E.; Marchetti, P.; Mathieu, C.; Overbergh, L. Glucagon-like peptide-1 protects human islets against cytokine-mediated beta-cell dysfunction and death: A proteomic study of the pathways involved. J. Proteome Res. 2013, 12, 4193-4206. [CrossRef] [PubMed]

170. Zhao, L.; Guo, H.; Chen, H.; Petersen, R.B.; Zheng, L.; Peng, A.; Huang, K. Effect of Liraglutide on endoplasmic reticulum stress in diabetes. Biochem. Biophys. Res. Commun. 2013, 441, 133-138. [CrossRef]

171. Yamane, S.; Hamamoto, Y.; Harashima, S.; Harada, N.; Hamasaki, A.; Toyoda, K.; Fujita, K.; Joo, E.; Seino, Y.; Inagaki, N. GLP-1 receptor agonist attenuates endoplasmic reticulum stress-mediated beta-cell damage in Akita mice. J. Diabetes Investig. 2011, 2, 104-110. [CrossRef]

172. Luo, X.; Pan, L.; Nie, A.; Wang, Q.; Gu, Y.; Li, F.; Zhang, H.; Li, W.; Li, X. Liraglutide protects pancreatic beta cells during an early intervention in Gato-Kakizaki rats. J. Diabetes 2013, 5, 421-428. [CrossRef] [PubMed]

173. Yusta, B.; Baggio, L.L.; Estall, J.L.; Koehler, J.A.; Holland, D.P.; Li, H.; Pipeleers, D.; Ling, Z.; Drucker, D.J. GLP-1 receptor activation improves beta cell function and survival following induction of endoplasmic reticulum stress. Cell Metab. 2006, 4, 391-406. [CrossRef]

174. Oh, Y.S.; Lee, Y.J.; Kang, Y.; Han, J.; Lim, O.K.; Jun, H.S. Exendin-4 inhibits glucolipotoxic ER stress in pancreatic beta cells via regulation of SREBP1c and C/EBPbeta transcription factors. J. Endocrinol. 2013, 216, 343-352. [CrossRef]

175. Kapodistria, K.; Tsilibary, E.P.; Kotsopoulou, E.; Moustardas, P.; Kitsiou, P. Liraglutide, a human glucagon-like peptide-1 analogue, stimulates AKT-dependent survival signalling and inhibits pancreatic beta-cell apoptosis. J. Cell Mol. Med. 2018, 22, 2970-2980. [CrossRef] [PubMed]

176. Shao, S.; Nie, M.; Chen, C.; Chen, X.; Zhang, M.; Yuan, G.; Yu, X.; Yang, Y. Protective action of liraglutide in beta cells under lipotoxic stress via PI3K/Akt/FoxO1 pathway. J. Cell. Biochem. 2014, 115, 1166-1175. [CrossRef]

177. Hao, T.; Zhang, H.; Li, S.; Tian, H. Glucagon-like peptide 1 receptor agonist ameliorates the insulin resistance function of islet beta cells via the activation of PDX-1/JAK signaling transduction in C57/BL6 mice with high-fat diet-induced diabetes. Int. J. Mol. Med. 2017, 39, 1029-1036. [CrossRef] [PubMed]

178. Chang, T.J.; Tseng, H.C.; Liu, M.W.; Chang, Y.C.; Hsieh, M.L.; Chuang, L.M. Glucagon-like peptide-1 prevents methylglyoxalinduced apoptosis of beta cells through improving mitochondrial function and suppressing prolonged AMPK activation. Sci. Rep. 2016, 6, 23403. [CrossRef] [PubMed]

179. Li, Z.; Zhou, Z.; Huang, G.; Hu, F.; Xiang, Y.; He, L. Exendin-4 protects mitochondria from reactive oxygen species induced apoptosis in pancreatic Beta cells. PLoS ONE 2013, 8, e76172. [CrossRef]

180. Yang, H.; Wang, S.; Ye, Y.; Xie, M.; Li, Y.; Jin, H.; Li, J.; Gao, L. GLP-1 preserves beta cell function via improvement on islet insulin signaling in high fat diet feeding mice. Neuropeptides 2021, 85, 102110. [CrossRef]

181. Jhala, U.S.; Canettieri, G.; Screaton, R.A.; Kulkarni, R.N.; Krajewski, S.; Reed, J.; Walker, J.; Lin, X.; White, M.; Montminy, M. cAMP promotes pancreatic beta-cell survival via CREB-mediated induction of IRS2. Genes Dev. 2003, 17, 1575-1580. [CrossRef] [PubMed]

182. Shin, S.; Le Lay, J.; Everett, L.J.; Gupta, R.; Rafiq, K.; Kaestner, K.H. CREB mediates the insulinotropic and anti-apoptotic effects of GLP-1 signaling in adult mouse beta-cells. Mol. Metab. 2014, 3, 803-812. [CrossRef] [PubMed]

183. Wang, K.; Liu, D.; Zhang, Y.; Chang, X.; Xu, R.; Pang, J.; Li, K.; Sun, P.; Zhu, Y.; Han, X. SAD-A, a downstream mediator of GLP-1 signaling, promotes the phosphorylation of Bad S155 to regulate in vitro beta-cell functions. Biochem. Biophys. Res. Commun. 2019, 509, 76-81. [CrossRef]

184. Abe, H.; Uchida, T.; Hara, A.; Mizukami, H.; Komiya, K.; Koike, M.; Shigihara, N.; Toyofuku, Y.; Ogihara, T.; Uchiyama, Y.; et al. Exendin-4 improves beta-cell function in autophagy-deficient beta-cells. Endocrinology 2013, 154, 4512-4524. [CrossRef] [PubMed]

185. Jing Yin, J.; Bo Li, Y.; Ming Cao, M.; Wang, Y. Liraglutide Improves the Survival of INS-1 Cells by Promoting Macroautophagy. Int. J. Endocrinol. Metab. 2013, 11, 184-190. [CrossRef]

186. Wang, J.; Wu, J.; Wu, H.; Liu, X.; Chen, Y.; Wu, J.; Hu, C.; Zou, D. Liraglutide protects pancreatic beta-cells against free fatty acids in vitro and affects glucolipid metabolism in apolipoprotein E-/- mice by activating autophagy. Mol. Med. Rep. 2015, 12, 4210-4218. [CrossRef]

187. Li, X.D.; He, S.S.; Wan, T.T.; Li, Y.B. Liraglutide protects palmitate-induced INS-1 cell injury by enhancing autophagy mediated via FoxO1. Mol. Med. Rep. 2021, 23, 1. [CrossRef] 
188. Arden, C. A role for Glucagon-Like Peptide-1 in the regulation of beta-cell autophagy. Peptides 2018, 100, 85-93. [CrossRef]

189. Fu, J.; Nchambi, K.M.; Wu, H.; Luo, X.; An, X.; Liu, D. Liraglutide protects pancreatic beta cells from endoplasmic reticulum stress by upregulating MANF to promote autophagy turnover. Life Sci. 2020, 252, 117648. [CrossRef]

190. Miao, X.; Gu, Z.; Liu, Y.; Jin, M.; Lu, Y.; Gong, Y.; Li, L.; Li, C. The glucagon-like peptide-1 analogue liraglutide promotes autophagy through the modulation of $5^{\prime}$-AMP-activated protein kinase in INS-1 beta-cells under high glucose conditions. Peptides 2018, 100, 127-139. [CrossRef]

191. Chen, X.; Huang, T.; Shi, Y.; Wang, L.; Li, W.; Shen, F.; Gu, X. A GLP1 receptor agonist attenuates human islet amyloid polypeptideinduced autophagy and apoptosis in MIN6 cells. Mol. Med. Rep. 2019, 19, 1365-1371. [CrossRef] [PubMed]

192. Fan, R.; Li, X.; Gu, X.; Chan, J.C.; Xu, G. Exendin-4 protects pancreatic beta cells from human islet amyloid polypeptide-induced cell damage: Potential involvement of AKT and mitochondria biogenesis. Diabetes Obes. Metab. 2010, 12, 815-824. [CrossRef]

193. Aston-Mourney, K.; Hull, R.L.; Zraika, S.; Udayasankar, J.; Subramanian, S.L.; Kahn, S.E. Exendin-4 increases islet amyloid deposition but offsets the resultant beta cell toxicity in human islet amyloid polypeptide transgenic mouse islets. Diabetologia 2011, 54, 1756-1765. [CrossRef]

194. Zhang, Y.; Warnock, G.L.; Ao, Z.; Park, Y.J.; Safikhan, N.; Ghahary, A.; Marzban, L. Amyloid formation reduces protein kinase B phosphorylation in primary islet beta-cells which is improved by blocking IL-1beta signaling. PLoS ONE 2018, 13, e0193184. [CrossRef]

195. Park, Y.J.; Ao, Z.; Kieffer, T.J.; Chen, H.; Safikhan, N.; Thompson, D.M.; Meloche, M.; Warnock, G.L.; Marzban, L. The glucagonlike peptide-1 receptor agonist exenatide restores impaired pro-islet amyloid polypeptide processing in cultured human islets: Implications in type 2 diabetes and islet transplantation. Diabetologia 2013, 56, 508-519. [CrossRef] [PubMed]

196. Pugazhenthi, S.; Qin, L.; Bouchard, R. Dipeptidyl peptidase-4 inhibition in diabetic rats leads to activation of the transcription factor CREB in beta-cells. Eur. J. Pharm. 2015, 755, 42-49. [CrossRef]

197. Hamamoto, S.; Kanda, Y.; Shimoda, M.; Tatsumi, F.; Kohara, K.; Tawaramoto, K.; Hashiramoto, M.; Kaku, K. Vildagliptin preserves the mass and function of pancreatic beta cells via the developmental regulation and suppression of oxidative and endoplasmic reticulum stress in a mouse model of diabetes. Diabetes Obes. Metab. 2013, 15, 153-163. [CrossRef]

198. Takeda, Y.; Fujita, Y.; Honjo, J.; Yanagimachi, T.; Sakagami, H.; Takiyama, Y.; Makino, Y.; Abiko, A.; Kieffer, T.J.; Haneda, M. Reduction of both beta cell death and alpha cell proliferation by dipeptidyl peptidase- 4 inhibition in a streptozotocin-induced model of diabetes in mice. Diabetologia 2012, 55, 404-412. [CrossRef]

199. Wu, Y.J.; Guo, X.; Li, C.J.; Li, D.Q.; Zhang, J.; Yang, Y.; Kong, Y.; Guo, H.; Liu, D.M.; Chen, L.M. Dipeptidyl peptidase-4 inhibitor, vildagliptin, inhibits pancreatic beta cell apoptosis in association with its effects suppressing endoplasmic reticulum stress in $\mathrm{db} / \mathrm{db}$ mice. Metabolism 2015, 64, 226-235. [CrossRef]

200. Omar, B.A.; Vikman, J.; Winzell, M.S.; Voss, U.; Ekblad, E.; Foley, J.E.; Ahren, B. Enhanced beta cell function and anti-inflammatory effect after chronic treatment with the dipeptidyl peptidase-4 inhibitor vildagliptin in an advanced-aged diet-induced obesity mouse model. Diabetologia 2013, 56, 1752-1760. [CrossRef]

201. Liu, L.; Liu, J.; Yu, X. Dipeptidyl peptidase-4 inhibitor MK-626 restores insulin secretion through enhancing autophagy in high fat diet-induced mice. Biochem. Biophys. Res. Commun. 2016, 470, 516-520. [CrossRef]

202. Matveyenko, A.V.; Dry, S.; Cox, H.I.; Moshtaghian, A.; Gurlo, T.; Galasso, R.; Butler, A.E.; Butler, P.C. Beneficial endocrine but adverse exocrine effects of sitagliptin in the human islet amyloid polypeptide transgenic rat model of type 2 diabetes: Interactions with metformin. Diabetes 2009, 58, 1604-1615. [CrossRef] [PubMed]

203. Shah, P.; Ardestani, A.; Dharmadhikari, G.; Laue, S.; Schumann, D.M.; Kerr-Conte, J.; Pattou, F.; Klein, T.; Maedler, K. The DPP-4 inhibitor linagliptin restores beta-cell function and survival in human isolated islets through GLP-1 stabilization. J. Clin. Endocrinol. Metab. 2013, 98, E1163-E1172. [CrossRef] [PubMed]

204. Bugliani, M.; Syed, F.; Paula, F.M.M.; Omar, B.A.; Suleiman, M.; Mossuto, S.; Grano, F.; Cardarelli, F.; Boggi, U.; Vistoli, F.; et al. DPP-4 is expressed in human pancreatic beta cells and its direct inhibition improves beta cell function and survival in type 2 diabetes. Mol. Cell Endocrinol. 2018, 473, 186-193. [CrossRef] [PubMed]

205. Campbell, S.A.; Golec, D.P.; Hubert, M.; Johnson, J.; Salamon, N.; Barr, A.; MacDonald, P.E.; Philippaert, K.; Light, P.E. Human islets contain a subpopulation of glucagon-like peptide- 1 secreting alpha cells that is increased in type 2 diabetes. Mol. Metab. 2020, 39, 101014. [CrossRef] [PubMed]

206. Traub, S.; Meier, D.T.; Schulze, F.; Dror, E.; Nordmann, T.M.; Goetz, N.; Koch, N.; Dalmas, E.; Stawiski, M.; Makshana, V.; et al. Pancreatic alpha Cell-Derived Glucagon-Related Peptides Are Required for beta Cell Adaptation and Glucose Homeostasis. Cell Rep. 2017, 18, 3192-3203. [CrossRef]

207. Augstein, P.; Naselli, G.; Loudovaris, T.; Hawthorne, W.J.; Campbell, P.; Bandala-Sanchez, E.; Rogers, K.; Heinke, P.; Thomas, H.E.; Kay, T.W.; et al. Localization of dipeptidyl peptidase-4 (CD26) to human pancreatic ducts and islet alpha cells. Diabetes Res. Clin. Pract. 2015, 110, 291-300. [CrossRef]

208. Omar, B.A.; Liehua, L.; Yamada, Y.; Seino, Y.; Marchetti, P.; Ahren, B. Dipeptidyl peptidase 4 (DPP-4) is expressed in mouse and human islets and its activity is decreased in human islets from individuals with type 2 diabetes. Diabetologia 2014, 57, $1876-1883$. [CrossRef]

209. Liu, L.; Omar, B.; Marchetti, P.; Ahren, B. Dipeptidyl peptidase-4 (DPP-4): Localization and activity in human and rodent islets. Biochem. Biophys. Res. Commun. 2014, 453, 398-404. [CrossRef] 
210. Zhang, Y.; Wu, M.; Htun, W.; Dong, E.W.; Mauvais-Jarvis, F.; Fonseca, V.A.; Wu, H. Differential Effects of Linagliptin on the Function of Human Islets Isolated from Non-diabetic and Diabetic Donors. Sci. Rep. 2017, 7, 7964. [CrossRef]

211. Marchetti, P.; Lupi, R.; Bugliani, M.; Kirkpatrick, C.L.; Sebastiani, G.; Grieco, F.A.; Del Guerra, S.; D'Aleo, V.; Piro, S.; Marselli, L.; et al. A local glucagon-like peptide 1 (GLP-1) system in human pancreatic islets. Diabetologia 2012, 55, 3262-3272. [CrossRef] [PubMed]

212. de Souza, A.H.; Tang, J.; Yadev, A.K.; Saghafi, S.T.; Kibbe, C.R.; Linnemann, A.K.; Merrins, M.J.; Davis, D.B. Intra-islet GLP-1, but not CCK, is necessary for beta-cell function in mouse and human islets. Sci. Rep. 2020, 10, 2823. [CrossRef] [PubMed]

213. Lin, H.V.; Wang, J.; Wang, J.; Li, W.; Wang, X.; Alston, J.T.; Thomas, M.K.; Briere, D.A.; Syed, S.K.; Efanov, A.M. GPR142 prompts glucagon-like Peptide-1 release from islets to improve beta cell function. Mol. Metab. 2018, 11, 205-211. [CrossRef] [PubMed]

214. Timper, K.; Dalmas, E.; Dror, E.; Rutti, S.; Thienel, C.; Sauter, N.S.; Bouzakri, K.; Bedat, B.; Pattou, F.; Kerr-Conte, J.; et al. Glucose-Dependent Insulinotropic Peptide Stimulates Glucagon-Like Peptide 1 Production by Pancreatic Islets via Interleukin 6, Produced by alpha Cells. Gastroenterology 2016, 151, 165-179. [CrossRef] [PubMed]

215. Vasu, S.; Moffett, R.C.; Thorens, B.; Flatt, P.R. Role of endogenous GLP-1 and GIP in beta cell compensatory responses to insulin resistance and cellular stress. PLOS ONE 2014, 9, e101005. [CrossRef]

216. Moffett, R.C.; Vasu, S.; Thorens, B.; Drucker, D.J.; Flatt, P.R. Incretin receptor null mice reveal key role of GLP-1 but not GIP in pancreatic beta cell adaptation to pregnancy. PLoS ONE 2014, 9, e96863. [CrossRef] [PubMed]

217. Gale, J.E.; Cox, H.I.; Qian, J.; Block, G.D.; Colwell, C.S.; Matveyenko, A.V. Disruption of circadian rhythms accelerates development of diabetes through pancreatic beta-cell loss and dysfunction. J. Biol. Rhythm. 2011, 26, 423-433. [CrossRef] [PubMed]

218. Ibrahim, M.; MacFarlane, E.M.; Matteo, G.; Hoyeck, M.P.; Rick, K.R.C.; Farokhi, S.; Copley, C.M.; O’Dwyer, S.; Bruin, J.E. Functional cytochrome P450 1A enzymes are induced in mouse and human islets following pollutant exposure. Diabetologia 2020, 63, 162-178. [CrossRef]

219. Qian, J.; Yeh, B.; Rakshit, K.; Colwell, C.S.; Matveyenko, A.V. Circadian Disruption and Diet-Induced Obesity Synergize to Promote Development of beta-Cell Failure and Diabetes in Male Rats. Endocrinology 2015, 156, 4426-4436. [CrossRef]

220. Khan, R.; Tomas, A.; Rutter, G.A. Effects on pancreatic Beta and other Islet cells of the glucose-dependent insulinotropic polypeptide. Peptides 2020, 125, 170201. [CrossRef]

221. Capozzi, M.E.; DiMarchi, R.D.; Tschop, M.H.; Finan, B.; Campbell, J.E. Targeting the Incretin/Glucagon System With Triagonists to Treat Diabetes. Endocr. Rev. 2018, 39, 719-738. [CrossRef] [PubMed]

222. Frias, J.P. Tirzepatide: A glucose-dependent insulinotropic polypeptide (GIP) and glucagon-like peptide-1 (GLP-1) dual agonist in development for the treatment of type 2 diabetes. Expert Rev. Endocrinol. Metab. 2020, 15, 379-394. [CrossRef] [PubMed]

223. Willard, F.S.; Douros, J.D.; Gabe, M.B.N.; Showalter, A.D.; Wainscott, D.B.; Suter, T.M.; Capozzi, M.E.; van der Velden, W.J.C.; Stutsman, C.; Cardona, G.R.; et al. Tirzepatide is an imbalanced and biased dual GIP and GLP-1 receptor agonist. JCI Insight 2020. [CrossRef] [PubMed] 